\title{
PENDIDIKAN AGAMA DALAM KELUARGA MENURUT NURCHOLISH MADJID
}

\author{
MUHASAR \\ MA. Jamiyyah Islamiyyah Tangerang Selatan \\ muhasar@madrasah.id
}

\begin{abstract}
ABSTRAK
Penelitian ini bertujuan untuk mengetahui peranan pendidikan agama dalam keluarga menurut Nurcholish Madjid. Adapun metode penelitian penyusunan skripsi ini penulis menggunakan penelitian kualitatif dengan metode deskriptif analisis. Yaitu pemecahan masalah yang ada dengan usaha menganalisis dan menjelaskan dengan teliti kenyataankenyataan faktual dari subjek yang diteliti sehingga diperoleh gambaran yang utuh berdasarkan fakta. Pendekatan yang penulis gunakan yaitu pendekatan content analisis, yaitu metode analisis yang menitik beratkan pada pemahaman isi dan maksud yang sebenarnya dari sebuah data. Hasil penelitian adalah bahwa peranan pendidikan dalam keluarga menurut Nurcholish Madjid tidak dapat sepenuhnya dilakukan oleh guru ngaji yang didatangkan kerumah. Pendidikan tersebut melibatkan peran orang tua dan seluruh anggota keluarga. Peran orang tua dalam memberikan pendidikan agama islam dalam keluarga tidak perlu berbentuk pengajaran (yang notabene dapat "diwakilkan" kepada orang lain). Peran orang tua adalah berupa tingkah laku, teladan, dan pola-pola hubungannya dengan anak yang dijiwai dan disemangati oleh nilai-nilai keagamaan secara menyeluruh. Pendidikan agama baru mempunyai makna yang hakiki jika menghantarkan manusia kepada tujuannya yang hakiki pula, yaitu kedekatan (taqarrub) kepada Allah dan kebaikan kepada sesama manusia (akhlaq karimah).
\end{abstract}

Kata Kunci: Pendidikan, Agama, Keluarga, Akhlak

\begin{abstract}
This study aims to determine the role of religious education in the family according to Nurcholish Madjid. The research method for preparing this thesis, the writer uses qualitative research with descriptive analysis method. Namely solving existing problems with an effort to analyze and explain carefully the factual facts of the subject under study in order to obtain a complete picture based on facts. The approach I use is the content analysis approach, which is a method of analysis that focuses on understanding the content and the true intentions of the data. The results of the study were that the role of education in the family according to Nurcholish Madjid could not be fully carried out by the Koran teachers brought home. Education involves the role of parents and all family members. The role of parents in providing Islamic religious education in the family does not need to take the form of teaching (which incidentally can be "represented" to others). The role of parents is in the form of behavior, role models, and patterns of relationships with children who are imbued and encouraged by religious values as a whole. New religious education has an intrinsic meaning if it brings people to their ultimate purpose, namely closeness (taqarrub) to God and kindness to fellow humans (akhlaq karimah).
\end{abstract}

Keywords: Education, Religion, Family, Morals 


\section{A. PENDAHULUAN}

Tanggung jawab pendidikan dalam islam adalah dengan dilaksanakannya kewajiban mendidik. Pengertian mendidik atau pendidikan dalam pengertian yang umum adalah untuk menumbuhkan dan mengembangkan potensi jasmaniah dan rohaniah anak didik atau seorang untuk mendapatkan nilai-nilai dan norma-norma tertentu. Kegiatan pendidikan tersebut dapat berlangsung dalam keluarga, sekolah, dan masyarakat. "Lembaga-lembaga tersebut yang ikut bertanggung jawab memberi pertolongan kepada anak didik atau seorang dalam perkembangan rohani dan jasmaninya, agar mencapai tingkat kedewasaan dan mampu berdiri sendiri memenuhi tugasnya sebagai makhluk Allah, makhluk sosial, dan sebagai makhluk individu" ${ }^{1}$

Ketiga lingkaran lingkungan tersebut yaitu keluarga, sekolah dan masyarakat adalah lingkungan yang dapat membentuk karakter manusia. Meski ketiganya saling mempengaruhi, tetapi pendidikan keluargalah yang paling dominan pengaruhnya terhadap pendidikan anak. Jika suatu rumah tangga berhasil membangun keluarga sakinah, maka peran sekolah dan masyarakat menjadi pelengkap. ${ }^{2}$ Seperti diketahui seorang bayi yang baru lahir adalah makhluk Allah SWT yang tidak berdaya dan senantiasa memerlukan pertolongan untuk dapat melangsungkan hidupnya di dunia. Maka bijaksana Allah SWT telah menganugerahkan rasa kasih sayang kepada semua ibu dan bapak untuk memelihara anaknya dengan baik tanpa mengharapkan imbalan. ${ }^{3}$ Seorang anak senantiasa selalu membutuhkan pendidikan karena pendidikan berusaha mengubah keadaan seseorang dari yang tidak tau menjadi tau, dari tidak dapat berbuat, dari bersikap yang tidak diharapkan menjadi bersikap seperti yang diharapkan. Kegiatan pendidikan ialah usaha untuk membentuk manusia secara keseluruhan aspek kemanusiaannya secara utuh, lengkap, dan terpadu. Secara umum dan ringkas dapat dikatakan pembentukan kepribadian. ${ }^{4}$ Oleh karena itu, manusia tidak bisa dipisahkan dari pendidikan. Pendidikan dapat membawa manusia kearah yang lebih baik. Terutama pendidikan pada masa anak-anak, kandungan hingga dilahirkan sampai mereka dewasa sampai memiliki kecerdasan intelektual, emosional dan spiritual yang matang.

Lingkungan keluarga sering pula disebut sebagai lembaga pertama dan utama pendidikan yang dikenal anak. Kedua orang tuanyalah orang yang pertama dikenal dan diterimanya pendidikan. Bimbingan dan perhatian dan kasih sayang yang terjalin antara kedua orang tua dan anak-anaknya,

${ }^{1}$ Djumaransjah Abdul Malik Karim Amrullah, Pendidikan Islam Menggali Tradisi Mengukuhkan Eksistensi, Cet. 1 (Malang: UIN Malang Press, 2007), 83.

2 Ahmad Mubarok, Psikologi Keluarga dari Keluarga Sakinah Hingga Keluarga Bangsa, Cet. 1 (Jakarta: PT.Bina Rena Pariwara, 2005), 152.

3 Abdul Majid, dkk., Pendidikan Agama Islam Berbasis Kompetensi (Bandung: PT. Remaja Rosdakaya, 2004), 11.

4 Proyek Pembinaan Perguruan Tinggi Agama/IAIN di Jakarta Direktorat Pembinaan Perguruan Tinggi Agama Islam, Metodologi Pengajaran Agama Islam (Jakarta: IAIN Jakarta, 1983), 60. 
merupakan basis yang ampuh bagi pertumbuhan dan perkembangan psikis serta nilai-nilai sosial dan religius pada diri anak didik. ${ }^{5}$ Munculnya gejala pendidikan dalam suatu keluarga disebabkan karena adanya pergaulan antara orang tua sebagai manusia dewasa dan anak yang belum dewasa. Dari situlah lahirlah peristiwa pendidikan dalam sebuah wadah yakni keluarga. "Kehadiran anak dalam keluarga merupakan tanggung jawab dan pengabdian orang tua terhadapnya, yang bersifat kodrati dan berdasarkan cinta kasih"'. ${ }^{6}$

Pendidikan dalam lingkungan keluarga bersifat pertama dan utama atau tertua, artinya pembiasaan atau tradisi untuk mengembangkan kepribadian anak adalah pertama kali terjadi dalam lingkungan keluarga. Alam keluarga adalah alam pendidikan yang pertama dan yang terpenting. Karena sejak timbulnya adat kemanusiaan hingga kini, hidup keluarga itu selalu mempengaruhi pertumbuhan budi pekerti manusia. Oleh karena itu, keluarga merupakan lembaga sosial yang paling dasar untuk mencetak kualitas manusia. Sampai saat ini masih menjadi keyakinan sebagai lembaga ketahanan moral, akhlaq alkarimah dalam konteks bermasyarakat, bahkan baik buruknya generasi suatu bangsa, ditentukan pula oleh pembentukan pribadi dalam keluarga. Disinilah keluarga memiliki peranan strategis untuk memenuhi harapan tersebut. ${ }^{7}$

Kehidupan keluarga di ibaratkan sebagai satu bangunan, demi terpeliharanya bangunan itu dari hantaman badai dan guncangan gempa, maka ia harus didirikan diatas fondasi yang kuat dengan bahan bangunan yang kokoh serta jalinan perekat yang lengket. "Fondasi kehidupan kekeluargaan adalah ajaran agama, disertai dengan kesiapan fisik dan mental calon-calon ibu dan ayah". 8 Pembinaan moral atau mental agama harus dimulai sejak anak lahir, oleh ibu bapaknya. Karena setiap pengalaman yang dilalui oleh anak- anak, baik melalui pendengaran, penglihatan, perlakuan, pembinaan dan sebagainya, akan menjadi bagian pribadinya yang akan bertumbuh nanti. "Apabila orang tuanya mengerti dan menjalankan agama dalam hidup mereka, yang berarti bermoral agama, maka pengalaman anak yang akan menjadi bagian dari pribadinya itu mempunyai unsur-unsur keagamaan pula'". ${ }^{9}$

Seperti diketahui pendidikan agama dalam keluarga, sebelum anak masuk sekolah terjadi secara tidak formil, yaitu melalui semua pengalaman anak, baik melalui ucapan, perbuatan dan sikap yang dilihatnya, maupun perlakuan yang dirasakannya". Oleh karena itu keadaan orang tua dalam kehidupan mereka

5 Samsul Nizar, Pengantar Dasar-dasar Pemikiran Pemikiran Pendidikan Islam, Cet. 1 (Jakarta: Gaya Media Pratama, 2001), 125.

${ }^{6}$ Fatah Yasin, Dimensi-Dimensi Pendidikan Islam (Malang: UIN Malang Press, 2008), 207.

7 Mufidah, Psikologi Keluarga Dalam Berwawasan Gender, Cet. 1 (Malang: UIN Malang Press, 2008), 39.

8 Muhammad Quraish Shihab, Membumikan Al-Qur'an Fungsi dan Peran Wahyu Dalam Kehidupan Masyarakat (Bandung: Mizan, 1994), 254.

9 Zakiah Drajat, Pendidikan Agama Dalam Pembinaan Mental, Cet. 15 (Jakarta: PT.Bulan Bintang, 1970), 61 . 
sehari-hari mempunyai pengaruh yang sangat besar dalam pembinaan kepribadian anak. ${ }^{10}$ "Untuk itu, semakin banyak pengalaman yang bernilai agamis mampu ditransfer dan diterimanya, maka akan banyak pula unsur agama dan pengalaman keagamaan yang mampu mewarnai proses pembentukan kepribadiannya. ${ }^{11}$

Sedemikian sangat berpengaruhnya pendidikan agama dalam keluarga bagi anak, tidak salah bila Rasulullah mengibaratkan seorang anak yang baru dilahirkan itu fitrah atau suci orang tualah yang menjadikan anak itu Yahudi, Majusi, atau Nasrani. Sebagai mana sabda Rasulullah SAW "Semua anak dilahirkan fitrah atau suci, orang tuanyalah yang menjadikannya Yahudi, Nasrani atau Majusi". (H.R Bukhori dan Muslim). Hadis ini pada intinya menyatakan bahwa setiap anak itu lahir dalam keadaan fitrah, maka kedua orang tuanyalah yang akan menjadikan ia Yahudi, Nasrani, atau Majusi. Kalau sampai menjadi Yahudi, Majusi, atau Nasrani orangtua mempertanggung jawabkannya". ${ }^{12}$ Dari kedua orang tua terutama ibu, dan untuk pertama kali pengaruh dari sesuatu yang dilakukan ibu itu secara tidak langsung akan membentuk watak atau ciri khas kepada anaknya. Ibu merupakan orang tua yang pertama kali sebagai tempat pendidikan anak. Karena ibu ibarat sekolah, jika ibu mempersiapkan anak berarti ibu telah mempersiapkan generasi yang kokoh dan kuat. Dengan generasi yang kuat berarti telah menginvestasikan sesuatu pada diri anak agar bermanfaat kelak mengarungi kehidupan yang lebih global. Itulah sebabnya pendidikan dalam keluarga disebut pendidikan yang pertama, serta merupakan peletak fondasi dari watak dan pendidikan anak.

Begitu besarnya tanggung jawab orang tua dalam mendidik anak. Maka Jalaludin dan Usman Said, ${ }^{13}$ menyebut tanggung jawab orang tua adalah pertama, mencegah anak dari kemungkaran dan selalu mengajak anak kepada kebaikan. Kedua, memberikan arahan dan binaan untuk selalu berbuat baik. Ketiga, beriman dan bertaqwa kepada Allah. Oleh karena itu tugas dan tanggung jawab orang tua adalah membimbing anak agar menjadi hamba yang taat menjalankan ajaran agama. Maka pendidikan tidaklah semata-mata menyekolahkan anak ke sekolah untuk menimba ilmu pengetahuan, namun lebih luas dari pada itu. Seorang anak akan tumbuh berkembang dengan baik manakala ia memperoleh pendidikan yang paripurna (komprehensif), agar ia kelak menjadi manusia yang berguna bagi masyarakat, bangsa, negara, dan agama. Anak yang demikian ini adalah anak yang sehat dalam arti luas, yaitu sehat fisik, mental, emosional, mental-intelektual, mental-sosial dan mental-

10 Zakiah Drajat, Ilmu Jiwa Agama (Jakarta: PT.Bulan Bintang, 1975), 109.

11 Samsul Nizar, Pengantar Dasar-dasar Pemikiran Pendidikan Islam, Cet. 1 (Jakarta: Gaya Media Pratama, 2001), 126.

12 Sudan, Al-Qur'an dan Panduan Kesehatan masyarakat (Yogyakarta: PT Drama Bakti Prima Yasa, 1997), 293.

${ }^{13}$ Fatah Yasin, Dimensi-Dimensi Pendidikan Islam, (Malang: UIN Malang Press, 2008), 206. 
spiritual. Pendidikan itu sendiri sudah harus dilakukan sedini mungkin terutama dalam lingkungan keluarga sebagai pencetak pertama generasi bangsa. ${ }^{14}$

Pendidikan agama dalam rumah tangga memang penting, tetapi itu tidak sepenuhnya sama dengan yang secara umum, dipahami dan dimaksud orang. Pertama-tama, pendidikan agama dalam rumah tangga tidak cukup hanya berupa pengajaran kepada anak tentang segi-segi ritual dan formal agama. Pengajaran ini, sebagaimana halnya yang ada di sekolah oleh guru agama, dalam rumah tangga pun dapat diperankan oleh orang lain, yaitu guru mengaji yang sekarang mulai populer dalam masyarakat kita. Dan meskipun ada guru mengaji yang sekaligus juga dapat bertindak sebagai pendidik agama, namun peran mereka tidak akan dapat menggantikan peran orang tua secara sepenuhnya. Jadi, guru mengaji pun sebenarnya terbatas perannya hanya sebagai pengajar agama yakni, penuntun ke arah segi-segi kognitif agama itu bukan pendidikan agama.

Jika yang dimaksudkan ialah pendidikan agama dalam rumah tangga ini, jelas melibatkan peran orang tua serta keseluruhan anggota rumah tangga dalam usaha menciptakan suasana keagamaan yang baik dan benar dalam keluarga. Dan peran orang tua tidak perlu berupa peran pengajaran (yang notabene dapat "diwakilikan" kepada orang lain). Peran orang tua adalah peran tinglah laku, tulada, atau teladan, dan pola-pola hubungannya dengan anak yang dijiwai dan disemangati oleh nilai-nilai keagamaan secara menyeluruh. Disinilah lebih-lebih akan terbukti benarnya pepatah, "Bahasa perbuatan adalah lebih fasih dari pada bahasa ucapan". Jadi jelas pendidikan agama menuntut tindakan percontohan lebih banyak dari pada pengajaran verbal. Dengan meminjam istilah yang populer di masyarakat (tapi sedikit salah kaprah), dapat dikatakan bahwa "pendidikan dengan bahasa perbuatan" (tarbiyat-un bi lisan -i l-hal) untuk anak adalah lebih efektif dan lebih mantab dari pada "Pendidikan dengan bahasa ucapan"(tarbiyat-un bi lisan-I l-maqal).

Karena itu yang penting ialah adanya penghayatan kehidupan keagamaan dalam suasana rumah tangga. Metode mendirikan mushala yang sekarang ini cukup banyak di praktikan orang dalam lingkungan rumah tangga adalah permulaan, bahkan modal, yang cukup baik. Kehadiran Mushala secara fisik dalam lingkungan keluarga akan menegaskan kehadiran rasa keagamaan dalam keluarga itu. Ini, secara "sibernetik"menyediakan prasarana pendukung bagi tumbuhnya kehidupan keagamaan yang akan membentukpendidikan keagamaan rumah tangga. Tetapi sebagaimana setiap prasarana fisik tidak dengan sendirinya menghasilkan apa yang dituju. Maka demikian pula mushala keluarga harus ditunjang dengan kegiatan keagamaan yang nyata. Meski shalat bersama masih termasuk segi ritual dan formal keagamaan, namun pelaksanaannya secara bersama dalam keluarga (dalam bentuk shalat berjamaah akan mempunyai dampak positif kepada seluruh anggota keluarga). Ada

14 Dadang Hawari, Al-Qur'an: Ilmu Kedokteran Jiwa dan Kesehatan Jiwa (Yogyakarta: PT Darma Bhakti Prima Yasa, 1996), 195-196. 
ungkapan inggris yang mengatakan, A family who prays together will never fall apart (Sebuah keluarga yang selalu berdoa atau sembahyang bersama tidak akan berantakan).

Sebagai "Bingkai" atau "Kerangka" keagamaan, Shalat adalah titik tolak yang sangat baik untuk pendidikan keagamaan seterusnya. Pertama, Shalat itu mengandung arti penguatan ketakwaan kepada Allah. memperkukuh dimensi vertikal hidup manusia, yaitu tali hubungan dengan Allah (habl min Allah). Segi ini dilambangkan dalam takbiratulihram, yaitu takbir atau ucapan Allahu Akbar pada pembukaan shalat; Kedua, Shalat itu menegaskan pentingnya memelihara hubungan dengan sesama manusia secara baik, penuh kedamaian, dengan kasih atau rahmat serta berkah Tuhan sehingga memperkuat dimensi horizontal hidup manusia, yaitu "tali hubungan dengan sesama manusia (habl min al-nas). Ini dilambangkan dalam taslimat atau ucapan salam, yakni ucapan Assalamualaikumwarahmatullahiwabarakatuh pada akhir shalat dengan anjuran kuat untuk menengok ke kanan dan ke kiri.

Banyak sekali petunjuk kitab suci tentang pendidikan secara hal-hal yang berkenaan dengan hubungan antara orang tua dan anak. Semuanya berkisar pada tanggungjawab orang tua terhadap anaknya dan kewajiban anak terhadap kedua orang tuanya. Hubungan yang saling bermanfaat dan saling membahagiakan antara orang tua dan (Sarikat Dagangan Islam), 1905, sebagai gerakan massa pertama yang besar dan diorganisasi secara politik dengan mudah ditafsirkan sebagai nasionalis, yang kuat. Agama mempunyai peranan yang sangat penting dalam kehidupan manusia, sebab agama merupakan motivasi hidup dan kehidupan merupakan alat pengembangan dan pengendalian diri yang amat penting. Oleh karena itu agama perlu diketahui, dipahami, dan diamalkan oleh manusia agar dapat menjadi dasar kepribadian sehingga ia dapat menjadi manusia yang utuh. ${ }^{15}$ Pada prinsipnya, pendidikan agama adalah pendidikan nilai-nilai agama, Pendidikan agama islam adalah transformasi nilai-nilai kepada anak agar menjadi hamba Allah yang beriman dan bertaqwa. Pendidikan agama juga pendidikan nilai atau internalisasi nilanilai agama. Beriman dan bertaqwa istilah-istilah yang Islami yang erat berkaitan dengan terminologi islam, anak yang beriman dan bertakwa dambaan setiap orang tua, hal itu dapat diwakili oleh istilah yang sudah umum yakni anak shaleh.

Hakikat anak shaleh adalah hamba yang selalu mengikatkan pola pikir dan pola sikapnya dengan aturan Allah dengan cara menjalankan seluruh perintah Allah dan menjauhi segala larangan Allah (beriman dan bertaqwa). Nilai-nilai yang baik ini adalah hal-hal yang diridhai oleh Allah dan nilai yang buruk adalah yang dibenci oleh Allah. nilai baik buruk dalam pandangan islam ukurannya adalah hukum islam yang berasal dari Allah dan tertera dalam AlQur'an dan Hadist. Ukuran nilai baik dan buruk adalah halal dan haram, bukan

${ }^{15}$ Rusmin Tumanggor, Ilmu Jiwa Agama (Jakarta: Kencana, 2013), 41. 
manfaat kemanusiaan sebagaimana dipahami oleh orang-orang Barat. Agama adalah nilai yang sangat penting bagi proses pendidikan anak untuk membentuk diri anak. Bagi agama adalah dasar dari tata nilai dan merupakan penentu dari dalam perkembangan dan pembinaan rasa kemanusiaan yang adil dan beradab, maka pemahaman dan pengalamannya dengan tepat dan benar maka diperlukan untuk lingkungannya. Agama bukan saja persoalan ibadah semata-mata, tetapi sebagai sistem hidup yang mengatur seluruh aspek kehidupan manusia. Orang tua, orang yang sangat dekat dengan anaknya perilaku dan sikapnya sehari-hari mestinya mencerminkan nilai-nilai agama yang akan menjadi contoh bagi anakanaknya. Pendidikan beragama bukan hanya untuk bersyukur kepada Allah tetapi harus juga memberikan dampak pada lingkungannya. Agama islam yang bersumber pada Al-Qur'an dan Assunnah memuat hal yang sangat lengkap, bukan saja soal ibadah mahdhah tetapi juga soal agar manusia mengelola alam, untuk itu diperlukan ilmu pengetahuan. ${ }^{16}$ Agama bagian yang mendorong hal itu, melaksanakan agama seperti shalat, puasa itu perlu ilmu pengetahuan, dan bahkan untuk melaksanakan haji misalnya datang ke kota suci makkah perlu sarana transportasi yang memerlukan ilmu dan teknologi. Banyak ayat AlQur'an dan Hadits tentang pentingnya ilmu ini. Ini juga Bagian dari pelaksanaan agama. Sikap orang tua memberikan dorongan yang maksimal agar anaknya cinta ilmu, tidak cukup hanya cinta ibadah. Orang tua menjadi contoh di rumah seperti melakukan kegiatan membaca di rumah baik oleh ayah maupun ibu. Mungkin bercerita tentang orang-orang yang mencintai ilmu pengetahuan dengan ketekunannya dan bercerita bahwa manusia hidup dengan mudah saat ini karena para ilmuan itu.

Kedua orang tua memiliki peran sentral bagi pendidikan agama dalam perspektif luas itu kepada anak-anaknya dirumah, baik melalui proses keteladanaan sikap dan perilaku dalam semua aspeknya. Menjadi orang tua dikaitkan dengan pendidikan agama atau beragama menjadi tidak mudah, diperlukan kematangan pribadi dan keshalehan perilaku. Bahkan dari anak belum lahir hingga lahir dan tumbuh besar, kedua orang tua harus terus memberikan pendidikan itu sesuai dengan aturan islam. ${ }^{17}$ Begitu anak lahir, dibisikkan di telinganya kalimah azan dan iqamah, dengan harapan kalimatkalimat thayibah itulah yang hendaknya yang pertama kali terdengar oleh anak, kemudian ia akan berulang kali mendengar, setiap waktu shalat tiba, baik didengarnya di rumah ataupun di luar rumah. Kata-kata thayyibah lainnya yang sering didengar oleh anak melalui ibunya, waktu ia disusukan, dimandikan, ditidurkan dan diganti pakaian oleh ibunya. Pengalaman anak, dan akan tetap hidup dalam jiwanya. Begitu pula ketika ia melihat bapak dan ibunya shalat, maka anak akan menyerap apa yang dilihatnya tersebut.

16 Hasbi Indra, Pendidikan Islam, Tantangan dan Peluang di Era Globalisasi (Yogyakarta: Deepublish, 2016), 143.

17 Ibdalsah, baiti, hal. 73. 
Peran orang tua sangat sentral sebagai pendidik di rumah. Orang tua dituntut memiliki kompetensi keilmuwan yang standar untuk melakukan proses pendidikan. Anak mungkin saja akan mengajukan berbagai pertanyaan tentang berbagai aspek kehidupan, Orang tua harus mampu menjawab dan menjelaskan dengan tepat. ${ }^{18}$ Sebab jawaban orang tua akan memberikan bekas dan pengaruh pada pemahaman anak dan akan dibawa hingga dewasa. Karenanya orang tua terutama ibu untuk bisa memberikan penjelasan yang benar terkait berbagai pertanyaan anak. Anak mengenal Tuhan melalui ucapan ibunya waktu ia kecil. apa yang dikatakan ibunya tentang Tuhan akan diterimanya dan dibawa sampai dewasa. Oleh karena itu, ibu perlu berhati-hati menjawab pertanyaan anak tentang Tuhan akan diterimanya dan dibawa sampai dewasa. Oleh karena itu, Ibu perlu berhati-hati menjawab pertanyaan anak tentang Tuhan atau pokokpokok keimanan lainnya. Jika ibu salah menjawab, maka pemahaman anak yang salah itu akan berkembang dalam jiwa anak nantinya. Dalam memperkenalkan sifat-sifat Allah pada anak, hendaklah didahulukan sifat-sifat Allah yang mendekatkan hatinya kepada Allah. Misalnya penyayang, pengasih, pemurah, adil dan sebagainya pada umur anak belum mencapai 12 tahun. Perlu diketahui bahwa kualitas hubungan anak dan orang tuanya akan mempengaruhi perilaku beragamanya di kemudian hari. Apabila ia merasa di sayang dan diperlakukan adil, maka ia akan meniru orang tuanya dan menyerap agama dan nilai-nilai yang dianut oleh orang tuanya. Dan jika yang terjadi sebaliknya, maka ia menjauhi apa yang diharapkan orang tuanya, mungkin ia tidak mau melaksanakan ajaran agama islam di dalam hidupnya, tidak solat, tidak puasa, dan sebagainya. ${ }^{19}$

Orang tua terutama ibu mampu melaksanakan pendidikan agama kepada anak-anak mereka, di rumahnya, yang mungkin dalam bentuk praktik beragama, yang ilmunya atau pengetahuannya sudah diberikan guru di sekolah. Pentingnya pendidikan agama untuk anak oleh kedua orang tuanya di rumah dikarenakan kondisi dan lingkungan yang bisa sangat berpengaruh terhadap warna pemahaman anak tentang agama. Hal ini terutama kondisi hari ini dengan berbagai kemajuan ilmu pengetahuan dan teknologi telah banyak membawa kemudahan hidup, termasuk televisi yang telah merambah masuk ke rumahrumah di seluruh pelosok tanah air, mulai dari kota hingga desa-desa, bahkan hingga desa terpencil. ${ }^{20}$ Maka apa saja yang ditayangkan oleh televisi dapat disaksikan oleh anak-anak, termasuk anak yang masih dibawah umur lima tahun, bahkan kadang-kadang bayi pun ada yang ikut menyaksikan. Sungguh besar pengaruh dalam kandungan telah mendapat pengaruh yang menyenangkan dan menjadi efek positif dalam kepribadiannya kelak. Perasaan

${ }^{18}$ Munawir Yusuf, Pendidikan Bagi Anak Dengan Problema Belajar (Solo: Tiga Serangkai, 2003), 45.

${ }^{19}$ Jalaluddin, Psikologi Agama, (Jakata: Rajawali Press, 2012), 78.

${ }^{20}$ Hasbi Indra, Pendidikan Islam, hal. 5. 
senang dan bahagia sang ibu memberi pengaruh terhadap sang anak melalui saraf-saraf pada rahim ibu. Sebaliknya bila ibu terguncang jiwanya akan berpengaruh pula. Hubungan yang baik antara suami dengan istri akan memberi dampak positif pada sang anak yang menjadi pembentukan pertama dalam pertumbuhan anak berikutnya.

\section{B. METODE}

Penelitian yang berjudul "Pendidikan Agama Dalam Keluarga Menurut Nurcholish Madjid". Ini dilaksanakan dari bulan Agustus 2019 sampai bulan september 2019 digunakan untuk pengumpulan data mengenai sumber-sumber tertulis yang diperoleh dari teks book yang ada di perpustakaan, serta sumber lain yang mendukung penelitian, terutama yang berkaitan dengan pendidikan agama dalam keluarga menurut Nurcholis Madjid.

Adapun teknik pengumpulan datanya dilakukan dengan mempelajari literatur yang ada hubungannya dengan masalah yang diteliti dengan mengumpulkan data-data melalui bahan bacaan dengan bersumber pada bukubuku primer dan buku-buku sekunder atau sumber sekunder lainnya. Data primer, yaitu buku-buku karya Nurcholish Madjid, antara lain: Masyarakat Religius, Pesan-pesan Taqwa (Kumpulan Kuthbah Jum'at di Paramadina, Pintupintu Menuju Tuhan, dan Tradisi Islam Peran dan Fungsinya dalam Pembangunan di Indonesia adalah landasan utama untuk menjadi rujukan dalam mengkaji masalah pendidikan agama dalam keluarga. Sedangkan data sekunder yang mendukung penelitian ini adalah beberapa buku-buku yang terkait dengan pendidikan.

Setelah data-data terkumpul lengkap, berikutnya yang penulis lakukan adalah membaca, mempelajari, meneliti, menyeleksi, dan mengklasifikasi datadata yang relevan dan yang mendukung pokok bahasan, untuk selanjutnya penulis analisis, simpulkan dalam satu pembahasan yang utuh.

Sebagai suatu kajian terhadap gagasan dari seorang tokoh, dalam hal ini metode penelitian ini penulis menggunakan penelitian kualitatif dengan metode deskriptif analisis. Yaitu pemecahan masalah-masalah yang ada dengan usaha menganalisis dan menjelaskan dengan teliti kenyataan-kenyataan faktual dari subjek yang diteliti sehingga diperoleh gambaran yang utuh berdasarkan fakta. ${ }^{21}$ Ditunjang oleh data-data yang diperoleh melalui penelitian kepustakaan (library research) yakni dengan membaca, menelaah, dan mengkaji buku-buku dan sumber tulisan yang erat kaitannya dengan masalah yang dibahas.

Pendekatan yang penulis gunakan yaitu pendekatan content analisis, yaitu metode analisis yang menitik beratkan pada pemahaman isi dan maksud yang sebenarnya dari sebuah data. Analisa data merupakan proses sistematis pencarian dan pengaturan, materi-materi yang lain yang telah terkumpul untuk

21 Wiranto Surahkmad,

Pengantar

Penelitian

Ilmiah

Dasar (Bandung:Tarsito:1998), 139. 
meningkatkan pemahaman penulis mengenai materi-materi tersebut dan untuk memungkinkan penulis menyajikan apa yang sudah ditemukannya kepada orang lain. Dalam penelitian ini, penulis menggunakan teknik Analisis Isi content analisis dalam bentuk deskriptif analisis yaitu berupa catatan informasi faktual yang menggambarkan segala sesuatu apa adanya dan mencakup penggambaran secara rinci dan akurat terhadap berbagai dimensi yang terkait dengan semua aspek yang diteliti. Maka, di sini penulis menggambarkan permasalahan yang dibahas dengan mengambil materi-materi yang relevan dengan permasalahan, kemudian dianalisis, dipadukan, sehingga dihasilkan suatu kesimpulan. ${ }^{22}$

\section{HASIL DAN PEMBAHASAN}

1. Hak dan kewajiban Orang tua Terhadap Anak Menurut Nurcholish Madjid

Orang tua mempunyai kewajiban memelihara anak dengan penuh tanggung jawab sebagai amanah Allah. Namun sebaliknya, orang tua pun mempunyai hak terhadap anak sebagai berikut pertama, anak-anak harus melayani orang tuanya dengan baik, lemah lembut menyayanginya, menghormati dan syukur atas jasa-jasa mereka terhadapnya. Anak-anak juga harus mematuhi perintah-perintahnya kecuali kalau menyuruh kepada yang bathil atau munkar.

Sebagaimana Allah telah berwasiat kepada kita semua umat manusia tentang banyaknya hal. Wasiat-wasiat Allah tersebut membentuk bagian amat penting dan ajaran Islam. "Salah satu ialah yang berkenan dengan ibubapak atau orang tua, Allah berwasiat kepada manusia bahwa mereka mutlak harus berbuat baik kepada orang tua". ${ }^{23}$

"Menurut Nurcholish Madjid hubungan antara anak dan orang tua dalam sistem ajaran Islam yang menyeluruh adalah perkara yang sangat penting setelah tauhid atau paham ketuhanan yang Maha Esa. Yaitu hubungan dalam bentuk perbuatan baik dari pihak anak kepada ayahibunya". ${ }^{24}$ Berbuat baik kepada orang tua dalam ajaran islam yang terdapat dalam kitab suci adalah perintah. Dan dalam suatu ayat disebutkan sebagai suatu "keputusan Tuhan" penilaian ini bisa disimpulkan dari firman-firman Allah:

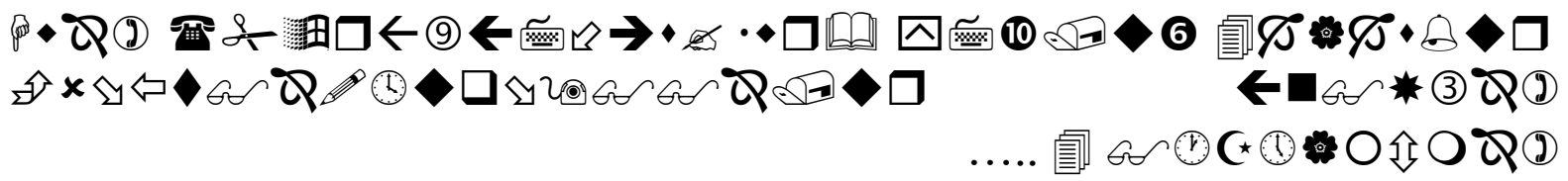

${ }^{22}$ Burhan Bungin, Penelitian Kualitatif: Komunikasi, Ekonomi, Kebijakan Publik, dan Ilmu Sosial Lainnya, Cet. 3 (Jakarta: Kencana, 2008), 155-159.

${ }^{23}$ Nurcholish Madjid, Pintu-pintu Menuju Tuhan, Cet. 6 (Jakarta: Paramadina, 2002), 136.

${ }^{24}$ Nurcholish Madjid, Masyarakat Religius, Cet. 1 (Jakarta, 1997), 111. 
Dan Tuhanmu telah memerintahkan supaya kamu jangan menyembah selain Dia dan hendaklah kamu berbuat baik pada ibu bapakmu..... (QS. Al-Isra:23). ${ }^{25}$

Dari ayat diatas dijelaskan betapa kewajiban berbuat baik kepada orang tua itu dinafaskan dalam suatu firman, merupakan kewajiban kedua setelah kewajiban manusia untuknya menyembah kepada Allah. ${ }^{26}$

Kemudian dalam ayat lain Allah berfirman :

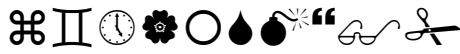

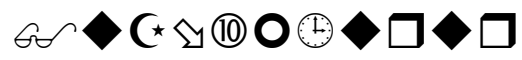

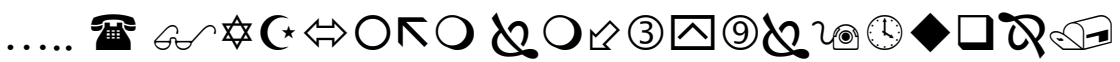

Dan kami berpesan kepada manusia (berbuat) kebaikan kepada dua orang ibubapaknya. (Qs Al-Ankabut:8). ${ }^{27}$

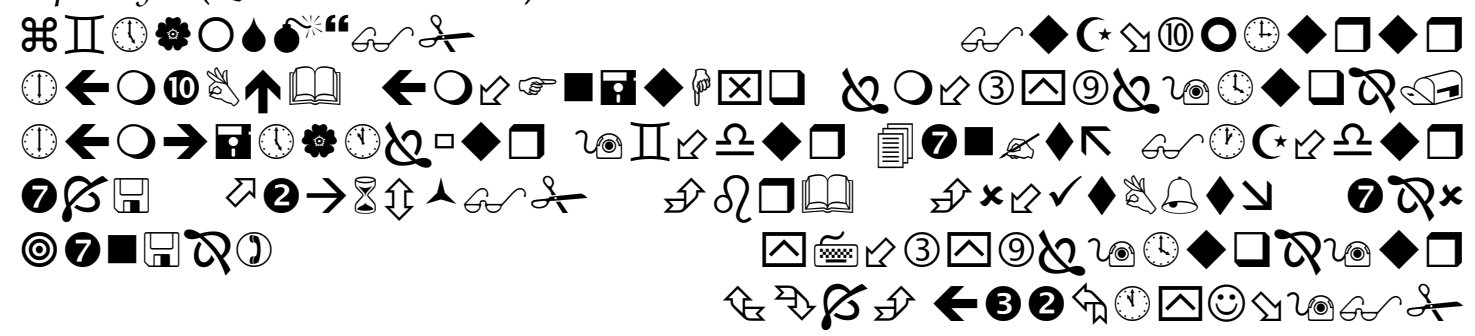

Dan Kami perintahkan kepada manusia (berbuat baik) kepada dua orang ibubapanya: ibunya telah mengandungnya dalam Keadaan lemah yang bertambahtambah, dan menyapihnya dalam dua tahun. bersyukurlah kepadaku dan kepada dua orang ibu bapakmu, hanya kepada-Kulah kembalimu.(QS. Luqman:14) ${ }^{28}$

Menurut Nurcholish Madjid, jika disimak lebih mendalam petunjukpetunjuk Ilahi, maka dapat ditarik kesimpulan betapa pentingnya hubungan orang tua dan anak dalam hidup ini, dan betapa ia terkait erat serta secara langsung dengan inti makna hidup itu sendiri. Yaitu, beribadah dan pasrah kepada Allah, Pencipta semesta alam dan manusia sendiri. Berkenaan dengan itu menurut Nurcholish Madjid, disini agaknya diperlukan kejelasan dan penegasan tentang suatu masalah. Tekanan "Keputusan" dan "Pesan" Allah kepada manusia berkenaan dengan kedua orang tua itu ialah pada kewajibannya berbuat baik kepada ibu bapaknya bukan pada kewajibannya taat atau menaati mereka. Berbuat baik meliputi makna yang luas dan mencakup banyak sekali jenis tingkah laku dan sikap anak kepada orang tua. Sedangkan taat hanyalah satu saja dari sekian banyak bentuk perbuatan baik tersebut,itu pun bersyarat.

Ketaatan anak kepada orang tua itu, seperti hanya dengan setiap bentuk ketaatan orang kepada siapa pun dan apa pun selain Allah

${ }^{25}$ Departemen Agama RI, Al-Qur'an dan Terjamahannya, (Bandung: 2007), 227.

${ }^{26}$ Nurcholish Madjid, Pintu-pintu Menuju Tuhan, Cet. 6 (Jakarta: Paramadina, 2002)

${ }^{27}$ Departemen Agama RI, Al-Qur'an dan Tarjamahnya, (Bandung:2007), 317.

${ }^{28}$ Departemen Agama RI, Al-Qur'an dan Tarjamahnya, (Bandung : 2007), h. 329. 
dibenarkan untuk dilakukan hanya dengan syarat bahwa ketaatan itu menyangkut kebenaran dan kebaikan, bukan kepalsuan dan kejahatan. Maka demikian jika halnya dengan ketaatan anak kepada orang tua dapat dan harus dilakukan hanya jika menyangkut suatu hal yang benar dan baik. Dalam keadan syarat itu terpenuhi, ketaatan anak kepada orang tua merupakan bagian dari kewajiban berbuat baiknya kepada mereka. Sedangkan dalam keadaan syarat itu tidak terpenuhi, ketaatan itu justru menjadi terlarang.

Tetapi sebaliknya, menurut Nurcholish Madjid "Keputusan" dan "Pesan" Tuhan agar orang berbuat baik kepada ibu-bapaknya adalah mutlak, tanpa syarat, bahkan sekalipun ibu-bapaknya itu jahat, sampai-sampai sekalipun ibu-bapanya itu secara sadar melawan kebenaran (kafir)" ${ }^{29}$

Begitulah ditegaskan dalam ajaran agama, seperti dalam ayat suci kelanjutan kutipan diatas

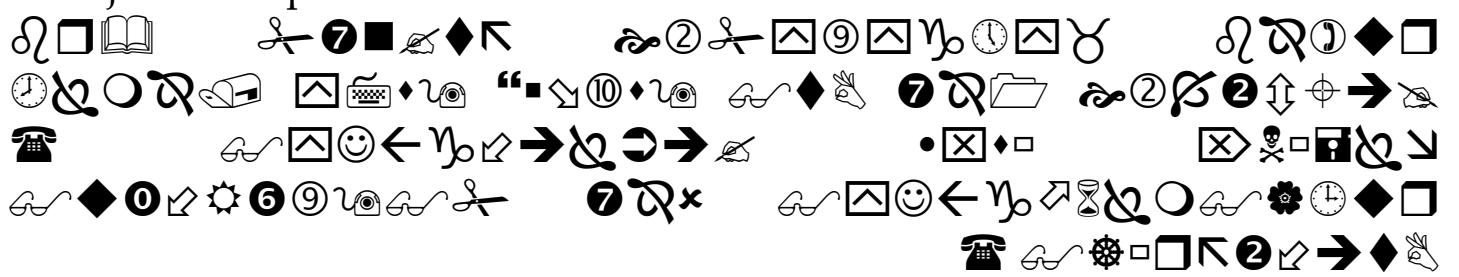

Dan jika keduanya memaksamu untuk mempersekutukan dengan aku sesuatu yang tidak ada pengetahuanmu tentang itu, Maka janganlah kamu mengikuti keduanya, dan pergaulilah keduanya di dunia dengan baik. (QS. Luqman:15). ${ }^{30}$

Juga terhadap keseluruhan keluarga dan kaum kerabat yang menyimpang pun seorang anak tetap diperintahkan Allah untuk meunjukkan sikap hormat dan sopan santun, meskipun anak itu dengan jelas tidak dapat menerima jalan hidup mereka.

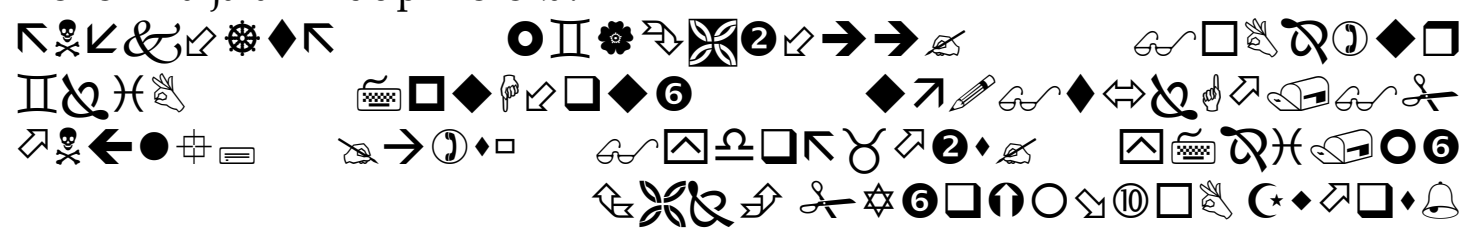

Dan jika kamu berpaling dari mereka untuk memperoleh rahmat dari Tuhanmu yang kamu harapkan, Maka Katakanlah kepada mereka Ucapan yang pantas.(QS. Al Isra:28) ${ }^{31}$

Menurut Nurcholish Madjid berdasarkan ayat-ayat diatas bahwasanya ketaatan anak terhadap orang tua hanya dituntut kepada sesuatu kebenaran (alhaqq) dan kebaikan ( $\left.m a^{\prime} r u f\right)$ dan jelas tidak dituntut dalam kepalsuan ( $A l$ bathil) dan kejahatan (al munkar). Tetapi orang tua tetap berhak mendapatkan perlakuan baik dari anaknya. Seorang anak dilarang berkata kasar terhadap orang tuanya sebaliknya seorang anak harus berlaku lemah lembut terhadap

\footnotetext{
${ }^{29}$ Nurcholish Madjid, Masyarakat Religius, Cet. 1, (Jakarta:Paramadina, 1997), h. 112-113.

${ }^{30}$ Departemen Agama RI, Al-Qur'an dan Tarjamahnya (Bandung: 2007), 329.

${ }^{31}$ Departemen Agama RI, Al-Qur'an dan Tarjamahanya, 227.
} 
orang tuanya sesuai apa yang menjadi " keputusan " dan "pesan" di dalam AL-Qur'an.

Sebagaimana ternyata dari firman suci yang dikutip dibagian pertama tadi, kewajiban anak berbuat baik kepada orang tua adalah pertama-tama dan terutama dituntut dalam hubungan dengan ibunya. Sebab tidak ada didunia ini yang sedemikian pengorbanannya untuk anak, dan tidak pula kecintaanya kepada anak demikian tulusnya seperti ibunya sendiri. " Dalam firman tadi dilukiskan oleh Allah, betapa ibu mengandung si anak dalam kesusahan, dan tidak bisa melepaskan atau memisahkan dirinya dari si anak selama dua tahun".

Mengenai hal ini sebuah sabda Rasulullah yang sering kali dikutip ialah yang menegaskan bahwa "syurga berada dibawah telapak kaki ibu". Makna dari hadist ini ialah bahwasanya jika seorang ingin " masuk syurga" maka ia harus berbuat baik kepada ibunya. "Bahwa hadist ini juga memantulkan tentang peranan ibu yang sangat besar bagi nasib anaknya, karena syurga itu berada sepenuh-penuhnya di bawah telapak kaki mereka", Hadist ini pun mengandug arti betapa besarnya tanggung jawab ibu terhadap masa depan anak. Dari segi kependidikan maka hadist tersebut ditunjukkan kepada ibu agar ia sadar, betapa besarnya tanggung jawab ibu terhadap anaknya, sampai kepada nasibnya diakhirat nanti. Sebagai mana janji Allah, bahwa kehidupan diakhirat nanti adalah kehidupan sebenarnya, didasarkan hasil perbuatan selama hidup di dunia. Bila amal shalehnya banyak, ia diberi kehidupan yang baik dan dimasukkan ke dalam syurga-Nya.

Dihubungkan dengan masalah pendidikan anak, hal tersebut mengandung arti timbal balik, bahwa sebagaimana pertama-tama anak harus berbuat baik kepada ibunya, maka begitu pula sang ibulah yang banyak mempengaruhi anaknya. Ini disebabkan bahwa hubungan emosional ibu dengan anak, jika tidak ada faktor-faktor lain yang luar biasa, umumnya terpatri rapat dan menjadi abadi, sampai anak menjadi dewasa.

Maka dari itu begitu pentingnya peranan ibu dalam pendidikan anaknya sampai ada sebuah syair yang mengatakan bahwasanya "ibu adalah sekolah, bila dipersiapkan dapat membentuk bangsa yang baik dan kuat". Maka syair tersebut mengandung arti bahwa seorang ibu mempunyai peran yang cukup signifikan dalam penumbuhan dan pengembangan pendidikan anak kedepan. Ibu diibaratkan sekolah didalamnya berperan menampung anak-anaknya untuk proses pendidikan (belajar-mengajar secara langsung) sehingga anak dapat tumbuh berkembang, baik jasmani maupun rohani.

Tetapi tentu saja yang bertanggung jawab atas pendidikan anak tidak hanya ibu. Meskipun tidak memiliki hubungan emosional dengan anak sehangat para ibu, kaum bapak pun ikut bertanggung jawab dalam pendidikan anak. Faktor yang paling menentukan peranan bapak ialah kedudukannya sebagai kepala keluarga. Ini tidak saja berarti sebagai “ 
penghasilan nasi" dalam keluarga, tetapi juga untuk anak fungsinya sebagai "image ideal". Para ahli umumnya mengatakan bahwa dalam jiwa anak yang ingin mencari suri tauladan dan bahkan "pahlawan", sang ayah selalu menempati urutan pertama, dan baru orang lain. Oleh karena itu pendidikan anak pun akan ikut ditentukan, berhasil atau gagalnya oleh "penampilan" sang ayah dalam penglihatan anak. ${ }^{32}$

Oleh karena itu peranan orang tua sangat besar pula menentukan pertumbuhan anak secara psikologis dan kultural. "Maka sudah selayaknya sebagai seorang anak dan diajarkan pula dalam agama untuk berbuat baik dan berterimakasih kepada orang tua. Dan selalu memohon doa kepada Allah agar memberikan rahmat kepada orang tua".33

\section{Orang Tua sebagai Pendidik bukan pengajar bagi Anak}

Jika menginsyafi lebih dalam lagi, bahwasanya harta benda dan anakanak adalah karunia ilahi, yang merupakan sebagai ujian atau percobaan (fitnah) bagi manusia, dan apakah manusia (orang tua) dapat memanfaatkan harta itu dan mendidik anak dengan baik atau tidak. Sebab tidak perlu diragukan lagi bahwa harta dan anak adalah unsur-unsur utama kehidupan manusia, yang membuatnya memperoleh kebahagiaan lahir dan duniawi. ${ }^{34}$

Karena "Harta" dan anak adalah kehidupan duniawi", maka juga sesungguhnya hidup di dunia ini adalah permainan, kesenangan, dan kemegahan serta saling bangga dan saling berlomba dalam harta dan anak". Jadi, sebagai fitnah, sisi lain dari harta dan anak ialah kemungkinan dengan mudah berubah dari sumber kebahagiaan menjadi sumber kesengsaraan dan kenistaan yang tidak terkira. Yaitu kalau kita tidak sanggup memanfaatkan harta dan mendidik anak tersebut dengan apa yang dipesankan dan amanatkan Allah.

Disebut cobaan, karena anak dan (harta) adalah batu penguji tentang siapa kita ini sebenarnya dari sudut kualitas hidup dan kepribadian kita. Sebab kualitas itu akan dengan sendirinya tercermin dalam apa yang kita lakukan kepada anak dan (harta) itu, menuju kebaikan ataukah membawa keburukan. Maka sebagai orang tua berkewajiban menuntun, membimbing, menumbuhkan anaknya menjadi orang shalih, yang bermanfaat dengan sesamanya dan dirinya sendiri. "Inilah bentuk kecintaan yang sejati seseorang kepada anak, Karena kecintaan serupa itu merupakan konsistensi kecintaan kepada Allah. Dan itulah pula salah satu pelaksanaan tanggung jawab keluarga adalah agar menjaga dan memelihara keluarganya dari hidup yang abadi. Sebagaimana firman Allah":

32 Nurcholish Madjid, Masyarakat Religius, Cet. 1 (Jakarta: Paramadina, 1997), 119

${ }_{33}$ Nurcholish Madjid, Pintu-pintu menuju Tuhan, Cet. 6 (Jakaarta: Paramadina, 2002), 137.

${ }^{34}$ Nurcholish Madjid, Masyarakat Religius, Cet. 1 (Jakarta: Paramadina, 1997), 121 


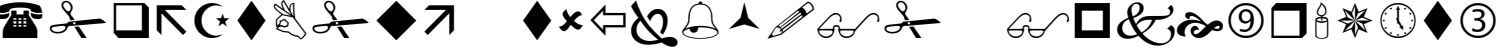

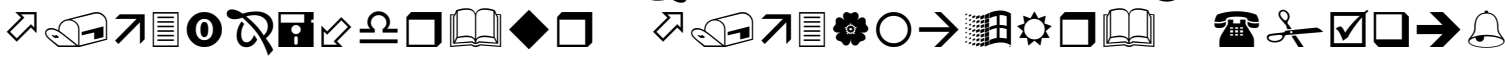

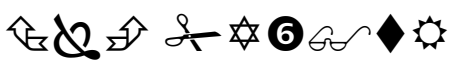

Hai orang-orang yang beriman, peliharalah dirimu dan keluargamu dari api neraka. (QS.Al-Tahrim[66]:6) ${ }^{35}$

Pembentukan atau pembinaan kepribadian anak berlangsung secara berangsur-angsur, bukanlah hal yang sekali saja, melainkan suatu hal yang berkembang, Apabila dalam pertumbuhannya anak mengalami proses yang baik dan benar, maka akan menghasilkan suatu kepribadian yang baik, matang dan harmonis.

Pendidikan agama dalam keluarga adalah unsur-pertama yang harus ditanamkan kepada anak. Karena jika diibaratkan sebuah bangunan maka agama adalah sebagai pondasi atau dasar dari bangunan tersebut. Perkembangan agama pada anak sangat tergantung dengan apa pendidikan dan pengalaman yang dilaluinya dalam keluarga, baik sejak masih dalam kandungan maupun dalam masa kanak-kanak. Kata-kata, sikap tindakan orang tua serta perhatian orang tua sangat mempengaruhi perkembangan keagamaan dan kepribadian anak. Dalam hal ini pembinaan kepribadian itu tidak terlepas dari pendidikan agama karena agama adalah sebagai landasan pembentukan kepribadian. Dengan demikian peranan agama adalah sebagai landasan pembentukan kepribadian. Dengan demikian peranan agama dalam keluarga sangat penting dalam menumbuh kembangkan kepribadian anak agar anak memiliki pribadi yang utama sesuai dengan petunjuk agama.

Menurut Nurcholis Madjid Pendidikan agama dalam keluarga tidak cukup hanya berupa pengajaran kepada anak tentang segi-segi ritual dan formal agama. Namun didalam masyarakat sering terjadi kekeliruan, orang tua sering melimpahkan tanggung jawab pendidikan agama kepada lembaga dan orang lain atau guru mengaji yang lebih populer dikalangan masyarakat. Tetapi yang sesungguhnya dapat dilimpahkan kepada lembaga lain atau guru mengaji terutama hanyalah pengajaran agama, berupa segi-segi ritual dan formal agama. Dan disini yang ditekankan adalah pendidikan agama yang diberikan orang tua kepada anak-anaknya. Sedangkan para pelaku pendidikan, seperti guru mengaji, dan guru agama disekolah adalah sebagai wakil-wakil orang tua dan pelanjut peran orang tua dalam menumbuhkan mengembangkan potensi keagamaan dalam diri anak. Meskipun ada guru mengaji sekaligus juga bertindak sebagai pendidik agama, namun peran mereka tidak akan dapat menggantikan peran orang tua sepenuhnya. Jadi guru mengaji pun sebenarnya terbatas perannya hanya sebagai pengajar agama, yakni penuntun ke arah segi-segi kognitif agama itu, bukan pendidikan agama.

\section{Pendidikan Agama dalam keluarga Menurut Nurcholish Madjid}

${ }^{35}$ Departemen Agama RI, Al-Qur'an dan Tarjamahnya, 447. 
Menurut Nurcholish Madjid pertumbuhan dan perkembangan anak tidak bisa dilihat hanya terbatas pada segi fisiknya saja, Justru tidak kurang pentingnya ialah usaha penumbuhan dan peningkatan yang tidak bersifat fisik, Yaitu, penumbuhan dan peningkatan potensi positif seorang anak agar mejadi manusia dengan tingkat kualitas yang setinggi-tingginya. Orang tua tidaklah berkuasa untuk membuat anaknya "baik", sebab potensi kebaikan itu sebenarnya justru sudah ada pada si anak".

Pertama kali dalam mempertimbangkan akal perbuatan ialah hati nurani. Hati nurani diberikan kepada kita oleh Allah sebagai petunjuk pertama hidup yang benar. Nurani artinya bersifat cahaya, seperti ruhani yang berasal dari kata ruh dan jasmani berasal dari kata jism, maka nurani berasal dari kata nur. Mengapa hati ini disebut nurani? Karena itulah modal azali, modal primodial dari Tuhan untuk menerangi hidup ini. Seperti firman Allah :

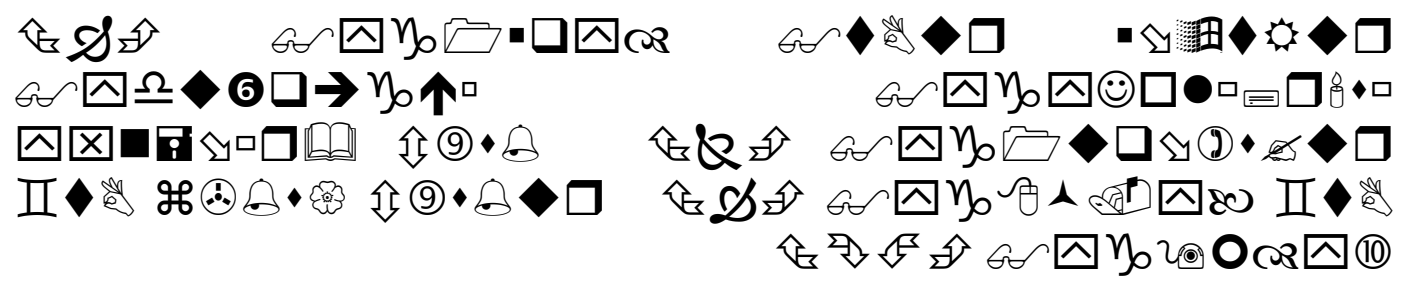

Dan jiwa serta penyempurnaannya (ciptaannya), Maka Allah mengilhamkan kepada jiwa itu (jalan) kefasikan dan ketakwaannya. Sesungguhnya beruntunglah orang yang mensucikan jiwa itu, Dan Sesungguhnya merugilah orang yang mengotorinya. (QS.Asyam: 7-10) ${ }^{36}$.

Dari ayat diatas jelas bahwasanya setiap jiwa manusia sudah memiliki kelengkapan dalam dirinya untuk mengetahui apa yang baik dan buruk, benar dan salah. "Kelengkapan itu adalah hati nurani". Sementra hati yang masih suci disebut nurani, maka dosa dalam Al-Qur'an yang paling banyak digunakan adalah kata zhulmun, Maka orang yang berdosa disebut zhalim, Sehingga orang yang terlalu banyak berbuat jahat dan tidak lagi memiliki Kesadaran, maka dia disebut tidak mempunyai nurani atau hatinya tidak memiliki sifat nurani". ${ }^{37}$

Rasulullah sendiri telah menegaskan dalam berbagai kesempatan, sebuah hadist meriwayatkan, ada sebuah Nabi bernama Wabishah yang kasar dan tidak terpelajar. Ia memaksa untuk menghadap Nabi pada waktu beliau sedang sibuk mengajar. Para sahabat menghalangi, tetapi dia dipanggil nabi dan ditanya. "Mengapa kamu mau datang? Ya saya tidak mau pergi sebelum saya mendapatkan keterangan tentang apa itu kebaikan dan keburukan. Nabi mengatakan bahwa kebaikan adalah sesuatu yang membuat hati tentram dan kejahatan ialah sesuatu yang membuat hati bergejolak meskipun kamu

${ }^{36}$ Departemen Agama RI, Al-Qur'an dan Tarjamahnya (Bandung: 2007), 447.

37 Nurcholish Madjid, Pesan-pesan Takwa Kumpulan Khutbah Jum'at di Paramadina, Cet. 4 (Jakarta: Paramadina, 2005), 93-95. 
didukung oleh seluruh umat manusia. Hadist ini jelas menerangkan bahwa pada dasarnya potensi kebaikan itu sudah ada pada diri manusia karena jika manusia melakukan kejahatan walaupun didukung oleh banyak manusia sesungguhnya hati tidak bisa menerimanya atau bergejolak.

Maka dari itu tugas orang tua ialah mengembangkan apa yang secara primordial sudah ada pada si anak, yaitu nature kebaikannya sendiri sesuai dengan fitrahnya. Sementara itu, di pihak lain orang tua mempunyai peranan menentukan dan memikul beban tanggung jawab utama yaitu jangan sampai terjadi pada diri si anak menyimpang dari nature dan potensi kebaikannya itu sehingga menjadi manusia dengan ciri-ciri kualitas rendah Inilah salah satu makna sebuah hadis yang amat terkenal, yang menegaskan betapa setiap anak dilahirkan dalam fitrah (nature kesucian),

kemudian ibu bapaknyalah yang berkemungkinan membuatnya menyimpang dari fitrah itu. ${ }^{38}$

Dalam kaitannya dengan pendidikan agama dalam keluarga, Menurut Nurcholish Madjid bahwa peran pendidikan agama sangat besar pengaruhnya dalam mewarnai kehidupan anak. Akan tetapi perlu direnungkan tentang apa yang di maksud agama? Diantara para mubalig dan tokoh agama ada yang memperingati bahwa bukanlah sekedar tindakan ritual seperti shalat dan membaca do'a saja. Agama lebih dari itu, yaitu keseluruhan tingkah laku manusia dan tingkah laku itu membentuk keutuhan manusia berbudi luhur (akhlakul karimah), atas dasar percaya atau iman kepada Allah dan tanggung jawab pribadi dihari kemudian demi memperoleh ridho Allah.

Karena itu renungan tentang apa yang dimaksud tentang pendidikan agama muncul secara logis, sebagai lanjutan dari renungan tentang apa itu agama. Karena agama yang dimaksud atas, maka dan segi-segi formalistiknya belaka. Ini tidak berarti pengingkaran terhadap perlunya ritusritus dan segi formalistik agama, tidak pula pengingkaran terhadap perlunya ritus-ritus dan segi-segi formal itu diajarkan kepada anak. Karena ritus-ritus dan itu di ibaratkan "bingkai" atau "kerangka" bagi bangunan agama. Karena itu setiap anak harus diajarkan bagaimana melaksanakan ritus-ritus itu dengan baik dengan memenuhi segala "syarat dan ruku" keabsahannya. ${ }^{39}$

Tetapi sebagi "bingkai" atau "kerangka" ritus dan formalitas bukanlah tujuan dalam dirinya sendiri. Ritus dan formalitas yang dalam hal ini terwujud dalam apa yang biasa disebut "rukun islam" " ritus dan formalitas keagamaan tersebut itu baru mempunyai mana yang hakiki jika menghantarkan orang yang bersangkutan kepada tujuannya yang hakii pula, yaitu kedekatan (taqarrub) kepada Allah dan kebaikan kepada sesama manusia (akhlaq karimah)".

${ }^{38}$ Nurcholish Madjid, Masyarakat Religius, Cet. 1 (Jakarta: Paramadina, 1997), 115.

${ }^{39}$ Nurcholish Madjid, Masyarakat Religius, 124. 
Maka menurut Nurcholish Madjid pendidikan agama dalam keluarga sesungguhnya adalah pendidikan agama berperan untuk pertumbuhan total seorang anak didik. Pendidikan agama tidak dapat dipahami secara terbatas hanya kepada pengajaran agama saja. Karena itu keberhasilan pendidikan agama bagi nak-anak tidak cukup diukur hanya dari segi seberapa jauh anak itu menguasai hal-hal yang bersifat kognitif atau pengetahuan tentang ajaran agama atau ritus-ritus keagamaan semata, Justru yang lebih penting, berdasarkan ajaran kitab dan sunnah sendiri, ialah seberapa jauh peran orangtua dapat menanamkan nilai-nilai keagamaan tersebut dalam jiwa anak, dan seberapa jauh pula nilai-nilai itu mewujud nyata dalam tingkah laku dan budi pekertinya sehari-hari. Perwujudan nyata nilai-nilai tersebut dalam tingkah laku dan budi pekerti sehari-hari akan melahirkan budi luhur atau alakhlaq al-karimah.

Menurut Nurcholis Madjid pendidikan agama dalam keluarga perlu ditanamkan ialah keterkaitan yang erat antara taqwa dan budi luhur dan juga makna keterkaitan antara iman dan amal saleh, salat dan zakat, hubungan dengan Allah (habl-un min al-lah) dan hubungan dengan sesama manusia (habl-un- minal-nas), ini juga terdapat pada bacaan takbir (lafal Allahu Akbar) pada pembukaan salat dan bacaan taslim (lafal Assalam-u'alaikum) pada penutupan shalat. Pendeknya, terdapat keterkaitan yang mutlak antara ketuhanan sebagai dimensi hidup petama manusia yang vertikal dengan kemanusiaan sebagai dimensi kedua hidup manusia yang horizontal. Oleh karena sedemikian kuatnya penegasan-penegasan dalam sumber-sumber suci agama (Kitab suci dan sunnah Nabi) mengenai keterkaitan antara kedua dimensi itu, maka pendidikan agama, baik di dalam keluarga maupun di sekolah, tidak dapat disebut berhasil kecuali jika pada anak didik tertanam dan tumbuh dengan baik kedua nilai itu: Ketuhanan dan Kemanusiaan, Taqwa dan Budi luhur. ${ }^{40}$

Mengapa ada keterkaitan antara takwa dan budi luhur? Menurut Nurcholish Madjid secara garis besar takwa itu ialah pola hidup atau gaya hidup kita menempuh hidup, yang disertai dengan kesadaran bahwa Allah itu hadir. Kesadaran bahwa Allah beserta kita mempunyai efek atau pengaruh yang besar sekali dalam hidup kita. Pertama, kesadaran itu memberikan kemantapan dalam hidup. Bahwa kita ini tidak pernah sendiri. Kemudian dampak kedua, bahwa dengan kesadaran hadirnya Allah dalam hidup ini, maka kita akan dibimbing kearah budi luhur, ke arah akhlakul karimah. Mengapa?" Karena kalau kita menyadari bahwa Allah selalu hadir dalam hidup kita, maka tentunya kita tidak akan melakukan sesuatu yang

${ }^{40}$ Nurcholish Madjid, Masyarakat Religius, Cet. 1, 133. 
kiranya tidak mendapat perkenaan dari Dia. Tidak mendapat ridho dari Dia (Allah). ${ }^{41}$

Dalam renungan lebih lanjut, penyebutan peranan Ayah dan Ibu oleh Nabi saw dalam hadist fitnah itu berarti bernada peringatan tentang kemungkinan pengaruh negatif orang tua dalam pendidikan anaknya sehingga ia bisa dari (nature) kesucian primordialnya. Ini tentu saja, harus di tafsirkan bisa terjadi jika Ayah Ibu kurang menyadari peran pengarahannya bagi pertumbuhan anak, maka sama saja membiarkan anak di bentuk oleh lingkungan "Sebab lingkungan turut andil juga dalam mempengaruhi watak dan akhlak anak, maka jika diibaratkan sebagi "stotz kontak" orang tua adalah yang paling besar setrumnya dibandingkan dengan lingkungan".

Orang tua berperan sebagai penyaring bagi anak dari segala pengaruh buruk yang terdapat dari lingkungan. Oleh karena itu kedua orang tua (ibu dan bapak) harus membekali diri dengan berbagai ilmu pengetahuan terutama ilmu agama, yang nantinya di transfer dan di internalisasikan kepada anak, serta orang tua dituntut untuk menyiapkan waktu yang cukup guna mendampingi dalam memberikan pendidikan bagi anaknya khususnya pendidikan agama.

\section{Nilai-nilai keagamaan yang ditanamkan pada diri Anak Menurut Nurcholish Madjid}

Adapun upaya-upaya yang dilakukan keluarga dalam hal menanamkan pendidikan keagamaan bagi anak menurut Nurcholish Madjid, penulis membatasi dalam hal sebagi berikut:

\section{a. Mendidik dengan keteladanan}

Pendidikan dengan keteladanan berarti pendidikan dengan memberi contoh, baik berupa tingkah laku, sifat, cara berfikir, dan sebagainya. Contoh atau teladanan yang baik dari orang tua akan membentuk kepribadian anak di masa perkembangan. anak pada masa perkembangan banyak mengadopsi pola perilaku apa saja yang ditampilkan oleh kehidupan dalam keluarganya, lebih-lebih pada ayah dan ibunya.

Pendidikan agama dalam keluarga, jelas melibatkan peran orang tua dan seluruh anggota keluarga dalam usaha menciptakan suasana keagamaan yang baik dan benar dalam keluarga.

Dan peran orang tua tidak perlu berupa peran pengajaran yang note bene nya dapat dialihkan kepada orang lain atau guru. Peran orang tua adalah peran tingkah laku tulada atau teladan. Seperti sebuah pepatah yang berbunyi " bahasa perbuatan adalah lebih fasih dari pada bahasa ucapan" (lisan -ul-hal-i- afshah-u min- lisa-il-maqal). Jadi jelas pendidikan agaman menuntut tindakan percontohan lebih-lebih dari pada pengajaran

${ }^{41}$ Nurcholish Madjid, Pesan-pesan Takwa Kumpulan Khutbah Jum'at di Paramadina, Cet. 4 (Jakarta: Paramadina, 2005), 233-234. 
verbal. Dengan meminjam istilah yang populer dimasyarakat, dapat dikatakan bahwa "pendidikan dengan bahasa perbuatan " (tarbiyah bi lisan-I'l-hal) untuk anak adalah lebih efektif dan lebih mantap dari pada "pendidikan dengan bahasa ucapan" ( tarbiyah bi lisan il-maqal). ${ }^{42}$

Para ahli umumnya mengatakan bahwasanya bila seorang anak mencari sosok suri teladan dan bahkan "pahlawan", seorang ayah selalu menempati urutan pertama, dan baru orang lain. Peranan seorang ayah terhadap pendidikan anak-anaknya sangat berpengaruh dalam pembentukan sikap dan tingkah laku mereka. Oleh karena itu apa dan bagaimana tingkah laku yang dilakukan seorang ayah akan berpengaruh juga pada tingkah laku anak-anak. Jika si ayah memberikan keteladanan sebagai penolong dalam keluarga, maka akan terkesan pula pada hati anak-anak akan keberhasilan didikan ayah terhadap anak-anaknya.

b. Membiasakan shalat Berjamaah

Sebagai "bingkai" atau kerangka keagamaan, shalat adalah titik tolak yang sangat baik untuk pendidikan keagamaan seterusnya. Pertamapertama, shalat itu mengandung arti penguatan ketaqwaan kepada Allah, memperkokoh dimensi hidup manusia, yaitu, "tali hubungan dengan Allah “ (Habl-un min al-lah). Segi ini dilambangkan dalam takbirat-u-'lihram, yaitu takbir atau ucapan Allahu Akbar pada pembukaan shalat. Kedua shalat itu menegaskan pentingnya memelihara hubungan dengan sesama manusia secara baik, penuh kedamaian, dengan kasih atau rahmat serta berkah Tuhan. Jadi memperkuat dimensi horizontal hidup manusia, yaitu "tali hubungan dengan sesama manusia" (habl-un min-al-nas). Ini dilambangkan dengan taslim atau ucapan salam pada akhir shalat dengan anjuran kuat dilambangkan dengan taslim atau ucapan salam pada akhir salat dengan anjuran kuat menengok kekanan dan kekiri. ${ }^{43}$

Salat pun sebetulnya dirancang agar kita senantiasa selalu ingat kepada Allah, Seperti firman Allah kepada Nabi Musa :

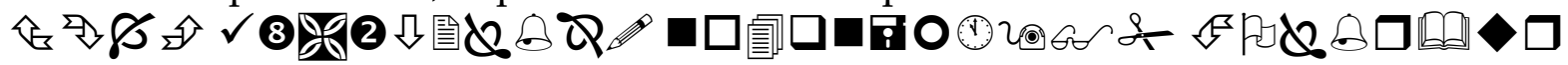

Dirikanlah salat untuk mengingat aku.. (QS. At-taha [20]:14) ${ }^{44}$

Dalam firman lain juga disebutkan bahwa salat itu mencegah dari perbuatan keji dan jahat.

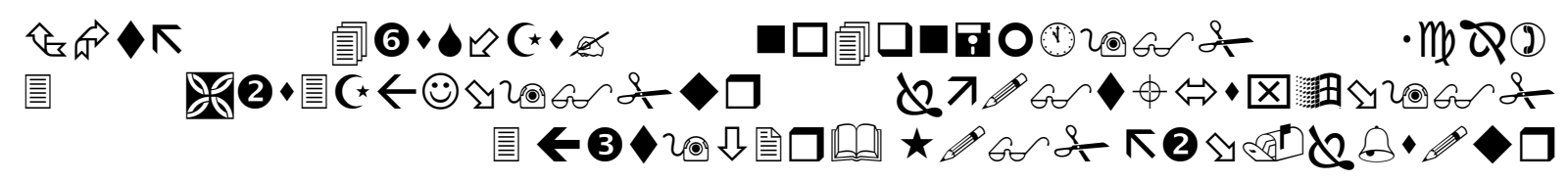

Sesungguhnya shalat itu mencegah dari (perbuatan- perbuatan) keji dan mungkar. dan Sesungguhnya mengingat Allah (shalat) adalah lebih

${ }^{42}$ Nurcholish Madjid, Masyarakat Religius, Cet. 1, 126-127.

${ }^{43}$ Departemen Agama RI, Al-Qur'an dan Tarjamahnya, 251.

${ }^{44}$ Departemen Agama RI, Al-Qur'an dan Tarjamahnya, 321. 
besar (keutamaannya dari ibadat-ibadat yang lain). (QS. Al-Ankabut $\{[29]: 45)$

" Kalimat wa ladzikkr-u I-lah-I akbar itu sendiri yang mengartikan sebagai penegasan tujuan dari shalat. Tapi juga ada yang mengartikan sebagai peringatan bahwa salat itu memang mencegah kita dari perbuatan jahat karena ingat kepada Allah. ${ }^{45}$

Anak yang masih kecil, kegiatan ibadah yang lebih menarik baginya adalah yang mengandung gerak, sedangkan pengertian tentang ajaran agama belum dapat dipahaminya karena itu, ajaran yang abstrak tidak menarik perhatiannya. Salah satu ibadah yang mengandung gerak adalah shalat. Anak-anak suka melakukan shalat meniru orang tuanya kendati pun ia tidak mengerti apa yang dilakukan itu. Pengalaman keagamaan yang menarik bagi anak diantaranya shalat berjama'ah.

Meskipun shalat bersama masih termasuk segi ritual dan formal keagamaan, namun pelaksanannnya secara bersama dalam keluarga dapat memberikan dampak yang sangat positif kepada seluruh anggota keluarga. Ada ungkapan Inggris yang mengatakan bahwa, "A family who pray together will never fall apart" (Sebuah keluarga yang selalu berdoa atau sembahyang bersama tidak akan berantakan). ${ }^{46}$

\section{c. Menanamkan Nilai Dimensi Hidup Ketuhanan dalam Diri Anak}

Pendidikan Islam, sering dikatakan memiliki sasaran dan dimensi hidup, yaitu penanaman rasa takwa kepada Allah dan pengembangan rasa kemanusiaan kepada sesamanya, dimensi hidup ketuhanan ini juga disebut jiwa rabbaniyah (QS. Al-Imron:79) atau biasa disebut tauhid rubuniyah, suatu bentuk keyakinan bahwa semua yang ada di alam semesta dikendalikan oleh Allah yang Maha Esa, tanpa campur tangan sekutu lain.

Adapun wujud nyata subtansi jiwa ketuhanan itu adalah nilai-nilai keagamaan yang harus ditanamkan dalam pendidikan. Dan jika dicoba merinci apa saja wujud nyata atau subtansi jiwa ketuhanan ini, maka kita dapatkan nilai-nilai keagamaan pribadi yang amat penting yang harus ditanamkan kepada anak. Kegiatan menanamkan nilai-nilai itulah yang sesungguhnya akan menjadi inti pendidikan keagamaan. Diantara nilainilai yang sangat mendasar adalah:

1) Takwa

Menurut Nurcholish Madjid kata taqwa itu sendiri merupakan serapan dari bahasa Arab yang biasa terjemahkan sebagi sikap takut kepada Allah atau sikap menjaga diri dari perbuatan jahat, atau sikap

${ }_{45}$ Nurcholish Madjid, Pesan-pesan Tuhan Kumpulan Khutbah Jum'at di paramadina, Cet. 4 (Jakarta: Paramadina, 2005), 101.

${ }^{46}$ Nurcholish Madjid, Masyarakat Religius, Cet. 1, 127 
patuh memenuhi segala kewajiban dan menjauhi segala larangan Allah.

Meskipun penjelasan itu semua mengandung kebenaran, tetapi belumlah merangkum seluruh tentang taqwa. "Takut kepada Allah" tidak mencakup segi positif taqwa, sedangkan sikap " menjaga diri dari perbuatan jahat" hanya menggambarkan satu segi saja dari keseluruhan makna taqwa. Muhammad Asad, seorang penerjemah dan penafsir al-Quran yang terkenal masa kini, menterjemahkan kata taqwa dengan menggunakan bahasa inggris "God Consiousness" yakni "kesadaran ketuhanan". Dan kesadaran ketuhanan sebagai uraian tentang taqwa sejiwa dengan perkataan "rabbaniyah" atau "ribbiyah" (semangat ketuhanan) yang dalam kitab suci di isyaratkan sebagai tujuan diutusnya para Nabi dan Rasul. Selanjutnya, yang dimaksud dengan "kesadaran atau semangat ketuhanan", Itu ialah seperti dijabarkan Muhammad Asad kesadaran bahwa Tuhan adalah Maha Hadir (Omnipresent) dan kesediaan untuk menyesuaikan keberadaan diri seseorang dibawah sorotan kesadaran itu. ${ }^{47}$

2) Iman

Iman yaitu sikap batin yang penuh kepercayaan kepada Allah. Jadi tidak cukup hanya percaya kepada adanya Allah, tetapi harus pula "mempercayai" Allah itu dalam kualitasnya sebagai satu-satunya yang bersifat keilahian atau ketuhanan, dan sama sekali tidak memandang adanya kualitas serupa kepada sesuatu apa pun yang lain. Selanjutnya dan sebagai konsekuensinya, karena kita mempercayai Allah, kita harus bersandar sepenuhnya kepadaNya, berpandangan positif kepadanya. "Menaruh kepercayaan kepadaNya".

Sebagai manusia kita harus berkeyakinan bahwa iman itu pasti akan membawa pengaruh kepada kehidupan. Dan pertama kali yang harus kita imani adalah Allah, bahwa barang siapa yang beriman kepada Allah, maka Allah berjanji akan menyediakan kehidupan yang baik didunia ini, dan juga kehidupan yang lebih baik di akhirat.

3) Islam.

Menurut Nurcholish Madjid Islam adalah sikap tunduk, patuh, atau taat kepada Tuhan yang semula digunakan untuk menunjukkan semangat yang kemudian digunakan sebagai nama yaitu, khususunya semangat dan nama agama yang dibawa Nabi Muhammad SAW. ${ }^{48}$ Dalam pengertian lain Nurcholish Madjid mengartikan Islam sebagai kelanjutan adanya iman, maka sikap pasrah kepadanya (yang

${ }^{47}$ Nurcholish Madjid, Tradisi Islam peran dan Fungsinya dalam pembangunan di indonesia. Cet. 1, (Jakarta: Paramadina), h. 141.

${ }^{48}$ Nurcholish Madjid, Tradisi Islam Peran dan Fungsinya dalam pembangunan di Indonesia, 140. 
merupakan makna asal perkataan arab islam), dengan meyakini bahwa apapun yang datang dari Tuhan tentu mengandung hikmah kebaikan, kita yang dhoif ini tidak mungkin mengetahui seluruh wujudnya. ${ }^{49}$

\section{4) Ikhlas}

Ikhlas yaitu sikap murni tingkah laku dan perbuatan, sematamata demi memperoleh ridho dan perkenaan Allah, dan bebas dari pamrih lahir dan bathin, tertutup maupun atau terbuka. Dengan sikap yang ikhlas orang akan mampu mencapai tingkat tertinggi nilai rasa batin dan lahirnya, baik pribadi maupun sosial". ${ }^{50}$ Nurcholish Madjid mengartikan keikhlaskan sama dengan taubat, yakni kembali kepada Allah. Begitu juga Inabah Wa anibu ila rabbikum wa aslim -u lah -u, yang artinya, "Kembalilah kepada Tuhanmu dan pasrahlah kepada-Nya". Terimalah apapun yang ada dari Tuhan itu tanpa persoalan. Ini juga yang disebut Ikhlas. Sedemikian halusnya Ikhlas itu sehingga dalam hadits kudsi disebutkan sebagai rahasia antara Tuhan dengan seorang hambanya yang saleh, al -Ikhlash-u sir-un min asrari, ikhlas itu adalah salah satu dari rahasiaku, awda tuhu qalba man ahbab-tuhu, yang aku titipkan dalam kalbu orang yang aku cintai, la ya' lam-u syaithan fayufsida, syaitan tidak mengetahui keikhlasan orang itu sehingga tidak bisa dirusak olehnya, wal la l-mala ikat-u fayaktub-uhu, dan malaikat pun juga tidak mengetahui keikhlasan seorang itu sehingga tidak bisa dicatat oleh malaikat. Karena ikhlas adalah rahasia antara kita dan Allah, maka untuk menjadi ikhlas kita memerlukan latihan terus menerus. ${ }^{51}$

5) Tawakal

Tawakal (dalam ejaan yang lebih tepat, ("tawakkul"): Yaitu sikap senantiasa bersandar kepada Allah, dengan penuh harapan kepadaNya dan keyakinan bahwa ia akan menolong kita dalam mencari dan menemukan jalan yang terbaik. Karena kita mempercayai atau menaruh kepercayaan kepada Allah, maka tawakkal adalah suatu kemestian". ${ }^{52}$ Kemudian tawakal dapat diartikan kesadaran yang mendalam bahwasanya Allah selalu beserta kita, mempunyai efek atau pengaruh yang besar sekali bagi hidup kita.

6) Syukur

Menurut Nurcholish Madjid syukur yaitu sikap penuh rasa terima kasih dan penghargaan, dalam hal ini atas segala nikmat dan karunia yang tidak terbilang banyaknya, yang dianugerahkan Allah kepada kita. Sikap bersyukur sebenarnya sikap optimis kepada hidup

${ }^{49}$ Nurcholish Madjid, Pintu-pintu menuju Tuhan, Cet. 6 (Jakarta: Paramadina, 2002), 2.

${ }^{50}$ Nurcholish Madjid, Masyarakat Religius, Cet. 1 (Jakarta: Paramadina, 1997), 131.

${ }^{51}$ Nurcholish Madjid, Pesan-pesan Takwa Kumpulan Khutbah Jum'at di paramadina, 107

52 Nurcholish Madjid, Masyarakat Religius, (Jakarta:Paramadina,1997) , Cet. I,131 
ini dan pandangan senantiasa berpengharapan kepada Allah. Karena itu sikap bersyukur kepada Allah adalah sesungguhnya sikap bersyukur kepada diri sendiri. Karena manfaat besar kejiwaannya yang akan kembali kepada yang bersangkutan. ${ }^{53}$

Rasa syukur sudah seharusnya ditingkatkan, syukur adalah pernyataan hati atas kecintaan pada zat yang memberi nikmat, gerak anggota tubuh dalam beribadah serta diungkapkan secara lisan dengan selalu mengingat-Nya dan memuji-Nya.

7) Sabar

Sabar dalam bahasa Arabnya al-shabr, yang arti sesunggunhnya adalah ketabahan, kesanggupan menahan diri, dan kesediaan untuk tidak mendahulukan kepentingan diri sendiri yang merugikan kepentingan orang banyak. ${ }^{54}$ Lebih lanjut lagi Nurcholish Madjid mengartikan sabar yaitu sikap tabah menghadapi segala kepahitan hidup, besar dan kecil lahir dan batin fisiologis mampu psikologis, karena keyakinan yang tak tergoyahkan bahwa kita semua berasal dari Allah dan kembali kepadanya, Jadi sabar adalah sikap batin yang tumbuh karena kesadaran akan asal dan tujuan hidup, yaitu Allah SWT..$^{5}$

\section{d. Menanamkan Nilai Dimensi Hidup Kemanusiaan dalam Diri Anak}

Di atas kita kemukakan beberapa nilai ketuhanan yang amat perlu ditanamkan kepada anak. Tentang nilai-nila budi luhur, sesungguhnya kita dapat mengetahuinya secara akal sehat atau "common sense" mengikuti hati nurani kita. Dan memang begitulah petunjuk Nabi, bahwa kita akan mengetahui amal perbuatan yang berbudi luhur jika kita rajin bertanya kepada hati nurani kita. Justru dalam agama islam hati kita disebut nurani (dari bahasa Arab, nurani artinya bersifat cahaya atau terang), karena baik menurut Al-Qur'an maupun sunnah nabi, hati kita adalah modal primordial untuk menerangi jalan hidup kita sehingga kita terbimbing kearah yang benar dan baik, yakni kearah budi luhur, "Tetapi sekadar untuk pegangan operatif dalam menjalankan pendidikan kegamaan kepada anak. Mungkin nilai-nilai akhlak berikut ini patut sekali dipertimbangkan oleh orang tua untuk ditanamkan kepada anak dan keturunannya adalah sebagai berikut". ${ }^{56}$

1) Silaturrahmi (dari bahasa arab, shilat al-rahm): yaitu pertalian rasa cinta kash antara sesama manusia, khususnya antara saudara, kerabat, handaitaulan, tetangga, dan sebagainya. Sifat utama Tuhan adalah

${ }_{53}$ Nurcholish Madjid, Masyarakat Religius, Cet. 1, 131.

${ }^{54}$ Nurcholish Madjid, Tradisi Islam Peran dan Fungsinya dalam Pembangunan di Indonesia, 143.

${ }_{55}$ Nurcholish Madjid, Masyarakat Religius, Cet. 1, 132.

${ }^{56}$ Nurcholish madjid, masyarakat religius, Cet. 1, 133. 
kasih. Sebagai satu-satunya sifat Ilahi yang diwajibkan sendiri atau dirinya. Maka manusia pun harus cinta kepada sesamanya, agar Allah cinta kepadanya. "kasihilah kepada orang di bumi, maka Dia (Tuhan) yang ada di langit akan kasih kepadamu".

2) Persaudaraan (ukhuwah): yaitu semangat persaudaraan, lebih-lebih sesama kaum beriman seperti disebutkan di Al-Qur'an, yang intinya ialah hendaknya kita tidak merendahkan golongan yang lain, kalaukalau mereka itu lebih baik dari pada kita sendiri, tidak saling menghina, saling mengejek, banyak berprasangka, suka mencari-cari kesalahan orang lain, dan suka mengumpat (membicarakan keburukan yang tidak ada di depan kita)

3) Persamaan (al-Musawwah): yaitu pandangan bahwa semua manusia tanpa memandang jenis kelamin, kebangsaan atau pun kesukaannya, dan lain-lain adalah sama dalam harkat dan martabat. Tinggi rendah manusia hanya ada dalam pandangan Tuhan yang tahu kadar Taqwa itu, Prinsip itu dipaparkan dalam kitab suci sebagai kelanjutan pemaparan tentang prinsip persaudaraan dikalangan kaum beriman. Jadi persaudaraan berdasarkan iman (ukhuwah islamiyah) .

4) Adil (dari perkataan Arab " $A d l$ "' ): yaitu wawasan yang seimbang atau balanced dalam memandang, menilai atau menyikapi sesuatu atau seseorang. Jadi tidak secara apriori menunjukkan sikap positif dan negatif. Sikap kepada sesuatu atau seseorang dilakukan hanya setelah mempertimbangkan segala segi tentang sesuatu atau seseorang tersebut secara jujur dan seimbang. Dengan penuh I'tikad baik dan bebas dari prasangka. Sikap ini juga disebut tengah dan Al-Qur'an menyebutkan bahwa kaum beriman dirancang oleh Allah untuk menjadi golongan tengah agar dapat menjadi saksi untuk sekian umat manusia, sebagai kekuatan penengah (wasith, indonesia "wasit")

5) Baik sangka (husn-u 'zh-zhan): yaitu sikap penuh baik sangka kepada sesama manusia, berdasarkan ajaran agama bahwa manusia itu pada asal dan hakekat aslinya adalah baik, karena diciptakan Allah dan dilahirkan atas fitrah atau kejadian asal yang suci. Sehingga manusia itu pun hakikatnya adalah makhluk yang kecenderungan kepada kebenaran dan kebaikan (hanif)

6) Rendah hati (tawadlu): yaitu sikap yang tumbuh karena keinsyafan bahwa segala kemuliaan hanya milik Allah, maka tidak sepantasnya manusia "mengklaim" kemuliaan itu kecuali dengan pikiran yang baik dan perbuatan yang baik, yang itu pun hanya Allah akan menilainya. Lagi pula kita harus rendah hati karena di atas setiap orang yang tahu (berilmu) adalah Dia yang maha Tahu (maha berilmu). Apabila sesama orang yang beriman, sikap rendah hati itu adalah suatu kemestian. 
Hanya kepada mereka yang jelas-jelas menentang kebenaran kita dibolehkan untuk bersikap "tinggi hati".

7) Dapat dipercaya ("al-amanah" "amanaah"): yaitu salah satu konsekuensi iman ialah amanah atau penampilan diri yang dapat dipercaya, Amanah sebagai budi luhur adalah lawan dari khianat yang amat tercela. Keteguhan masyarakat memerlukan orang-orang para anggotanya yang terdiri dari pribadi-pribadi yang penuh amanah dam memiliki rasa tanggung jawab yang besar.

8) Tepat Janji (al-Waffa): yaitu salah satu sifat orang yang benar-benar beriman ialah sikap selalu menepati janji bila membuat perjanjian. Dalam masyarakat dengan pola hubungan yang lebih kompleks dan luas, sikap janji lebih-lebih lagi merupakan unsur budi luhur yang amat diperlukan dan dipuji.

9) Perwira (ifah atau ta'afuff): yaitu sikap penuh harga diri namun tidak sombong, dan tidak mudah menunjukkan sikap memelas atau iba dengan maksud mengundang belas kasihan orang lain dan mengharapkan pertolongannya.

10) Lapang dada (insyirah): yaitu penuh sikap kesediaan menghargai orang lain dengan pendapat-pendapat dan pandangan-pandangannya, seperti dituturkan dalam Al-Qur'an mengenai sikap Nabi sendiri disertai pujian kepada beliau. Sikap terbuka dan toleransi serta kesiapan bermusyawarah secara demokratis terkait erat sekali dengan budi luhur lapang dada ini.

11) Dermawan (al-munfiqun), menjalankan infaq): yaitu sikap kaum beriman yang memiliki kesediaan yang besar untuk menolong sesama manusia. Terutama mereka yang kurang beruntung (para fakir miskin dan terbelenggu oleh perbudakan dan kesulitan hidup lainnya), dengan mendermakan sebagian harta benda yang dikaruniakan diamanatkan Tuhan kepada mereka, Sebab manusia tidak akan memperoleh kebaikan sebelum mendermakan sebagian dari harta benda yang dicintainya itu. ${ }^{57}$

12) Hemat (qawamiyah): yaitu sikap tidak boros (israf) dan tidak pula kikir (qatr) dalam menggunakan harta, melainkan sedang qawwam antara keduanya. Apalagi Al-Quran, menggambarkan bahwa orang yang boros adalah teman setan yang menentang Tuhannya.

Pendidikan akhlak didalam keluarga dilaksanakan dengan contoh dan teladan dari orang tua. Perilaku dan sopan santun orang tua dalam hubungan dan pergaulan ibu dan bapak, perlakuan dengan orang tua terhadap anak-anaknya dan perlakuan orang tua terhadap orang lain di dalam lingkungan keluarga dan lingkungan masyarakat, akan menjadi

${ }^{57}$ Nurcholis Madjid, Masyarakat Religius, Cet. 1, 137. 
teladan bagi anak-anak. Sama halnya dengan nilai-nilai ketuhanan yang membentuk ketakwaan tersebut di muka, nilai-nilai kemanusiaan yang membentuk akhlak mulia di atas itu tentu masih bisa ditambah dengan deretan nilai yang banyak sekali. Namun kiranya yang tersebut di atas itu akan sedikit membantu mengidentifikasi agenda pendidikan agama dalam keluarga yang lebih konkrit dan operasional. Sekali lagi, pengalaman nyata orang tua dan pendidik akan membawanya kepada kesadaran akan nilai-nilai budi luhur lainnya yang lebih relevan untuk perkembangan anak.

Tanggung jawab pendidikan anak ini sungguh amat berat, Khususnya bagi orang tua. Karenanya kita hendaknya tidak putus-putus memohon pertolongan kepada Allah untuk memperoleh bimbingan dan petunjuknya. "Seperti pengakuan yang lebih mendalam dalam ajaran kesufian islam, manusia tidak akan mampu melaksanakan apa-apa, termasuk melaksanakan perbuatan baik seperti mendidik anak, jika tanpa bantuan dan bimbingan Allah, karena tiada daya, tiada pula kemampuan, kecuali dengan Allah yang Maha Tinggi dan Maha Agung".

\section{e. Pola Asuh Menurut Nurcholish Madjid}

Pola Asuh adalah tata sikap dan perilaku orang tua dalam membina kelangsungan hidup anak, perlindungan anak secara menyeluruh baik fisik, sosial maupun rohani, Pola asuh juga berarti cara atau model dan sikap orang tua dalam merawat mendidik anak dalam mengembangkan seluruh aspek pada diri anak. Menurut Nurcholish Madjid berkaitan dengan pendidikan agama dalam keluarga, mengasuh atau mendidik anak orang tua sangat berperan aktif dalam menumbuh kembangkan pendidikan moral dan agama anak. Dan peran orang tua adalah tulada atau keteladanan yang dijiwai dengan semangat menanamkan nilai-nilai religius dalam diri anak. Orang tua tidak hanya mengajarkan anak tentang bagaimana ritual-ritual dalam beribadah seperti shalat, puasa, zakat dan lainnya, Namun lebih dari itu, orang tua dituntut untuk lebih menekankan tentang nilai-nilai apa yang terkandung dalam ritual-ritual tersebut, yang kemudian nilai-nilai tersebut di aplikasikan dalam kehidupan sehari-hari. Dan pendidikan agama sejatinya baru mempunyai makna yang hakiki jika menghantarkan orang yang bersangkutan kepada tujuannya yang hakiki pula, yaitu kedekatan (taqarrub) kepada Allah dan kebaikan kepada sesama manusia (akhlaqul alkarimah).

\section{KESIMPULAN}

Dari penelitian ini dapat disimpulkan bahwa pandangan Nurcholish Madjid tentang pendidikan agama dalam keluarga adalah Tidak dapat 
sepenuhnya dilakukan oleh guru ngaji yang didatangkan kerumah. Pendidikan tersebut melibatkan peran orang tua dan seluruh anggota keluarga. Dan peran orang tua dalam memberikan pendidikan agama dalam keluarga tidak perlu berbentuk pengajaran (yang notabene dapat "diwakilkan" kepada orang lain tersebut). Peran orang tua adalah berupa tingkah laku, tulada atau teladan, dan pola-pola hubungannya dengan anak yang dijiwai dan disemangati oleh nilainilai keagamaan secara menyeluruh. Pendidikan agama baru mempunyai makna yang hakiki jika menghantarkan orang yang bersangkutan kepada tujuannya yang hakiki pula, yaitu kedekatan (taqarraub) kepada Allah, dan kebaikan kepada sesama manusia (akhlaqul al-karimah). Adapun nilai-nilai keagamaan yang harus ditanamkan pada anak dalam keluarga adalah : a.) Shalat berjama'ah b.) Taqwa, c.) Iman, d.) Islam, e.) Tawakal, f.) Syukur, g.) Sabar, dan h.) Akhlaqul karimah.

Penelitian ini menyarankan agar peranan pendidikan agama dalam keluarga masih kurang memuaskan atau mungkin masih dianggap kurang memadai dalam mendidik anak, namun setidaknya dapat dijadikan masukan bagi masyarakat terutama orang tua dan para pendidik. Pemikiran tokoh ini dapat dijadikan studi banding oleh peneliti lainnya dalam mewujudkan anak yang cerdas, iman, dan takwa. Hendaknya para orang tua dapat menjadi uswah hasanah bagi anaknya dengan menjaga sikap dan tingkah lakunya di hadapan anak-anaknya, Serta mendidik anak-anaknya dengan penuh kasih sayang serta memperhatikan perkembangan dari berbagai aspek keagamannya. 


\section{DAFTAR PUSTAKA}

Ahmad, Sastra Filosofi Pendidikan Islam, Bogor: Darul Muttaqin Press, 2014.

Ahmadi Abu, Ilmu Sosial Dasar, Jakarta: PT Rineka Cipta,1999.

Agoes Dariyo,Psikolog Perkembangan Aditama, Bandung: PT. Refika Aditama, 2007, Penerbit Mizan,1983.

Ali, Muhammad Daud, hukum islam: pengantar ilmu hukum dan tata hukum islam di indonesia, Jakarta: Rajagrafindo persada, 1998.

Al-Quussy Abdul Aziz, Ilmu Jiwa, Prinsip-prinsip dan Implementasinya Dalam Pendidikan, Jakarta: Bulan Bintang, 2002.

AR. Baharuddin, Filsafat Pendidikan Islam,

Arif Armai, Reformulasi Pendidikan Islam, Jakarta: CRSD Press, 2005.

Azhary, Muhammad Tahir, Negara Hukum: Suatu studi tentang prinsip-prinsipnya dilihat dari segi hukum islam, implementasinya pada priode negara madinah dan masa kini, Jakarta: Kencana,

Aziz, Ahmad Amir, Neo-Modernisme Islam Di Indonesia Gagasan Sentral Nurcholish Madjid dan Abdurahman wahib, Jakarta: PT. Rineka Cipta, 1999.

Bungin Burhan, Penelitian Kualitatif: Komunikasi, Ekonomi, Kebijakan Publik, dan Ilmu Sosial Lainnya, Jakarta: Kencana, 2008.

Departemen Agama RI, Al-Qur'an dan Terjamahannya, Bandung: 2007.

Departemen Pendidikan dan Kebudayaan, Kamus Besar Bahasa Indonesia Edisi kedua, Jakarta: Balai Pustaka, 1996.

Depdikbud, Kamus Besar Bahasa Indonesia, Jakarta: Balai Pustaka,1988.

Djumaransjah, Abdul Malik Karim Amrullah, Pendidikan Islam Menggali Tradisi Mengukuhkan Eksistensi, Malang: UIN Malang Press, 2007.

Drajat Zakiah, Ilmu Jiwa Agama, Jakarta: PT. Bulan Bintang, 1975.

Drajat Zakiah, Ilmu Pendidikan Islam, Jakarta: Bumi Aksara, 1996.

Drajat Zakiah, Pendidikan Agama Dalam Pembinaan Mental, Jakarta: PT. Bulan Bintang, 1970.

Drajat Zakiah,Pendidikan Islam Dalam Keluarga Dan Sekolah, Jakarta: CV.Ruhama,1995. 
Fuaduddin, Pengasuhan Anak Dalam Keluarga Islam, Jakarta: Lembaga Kajian Agama dan Jender, 1999.

Hafizh, Muhamad Nur Abdul, Mendidik Anak Bersama Rasulullah saw, Bandung: Albayan, Kelompok Penerbit Mizan, 1983.

Hawari Dadang, Al-Qur'an: Ilmu Kedokteran Jiwa dan Kesehatan Jiwa, Yogyakarta: PT Darma Bhakti Prima Yasa, 1996.

Ibdalsah, baiti,

Ibdalsah, Baiti-Baiti, Bogor: Azam, 2014.

Indra Hasbi,Pendidikan Islam, Tantangan dan Peluang di Era Globalisasi, Yogyakarta: Deepublish, 2016.

Ismail Faisal, Membongkar Kerancuan Pemikiran Nurcholish Madjid, Jakarta: Lasswell, 2010.

Jalaludin, Psikologi Agama, Jakarta: PT. Rajagrafindo, 2005.

Jalaluddin, Psikologi Agama, Jakarta Rajawali Press, 2012.

Madjid Abdul, dkk. Pendidikan Agama Islam Berbasis Kompetensi, Bandung: PT. Remaja Rosdakaya, 2004.

Madjid Nurcholish, Masyarakat Religius, Jakarta: Paramadina, 1997.

Madjid Nurcholish, Pintu-pintu Menuju Tuhan Jakarta: Paramadina, 2002.

Madjid Nurcholish, Pesan-pesan Takwa Kumpulan Khutbah Jum'at di Paramadina, Jakarta: Paramadina, 2005.

Mubarok Ahmad, Psikologi Keluarga dari Keluarga Sakinah Hingga Keluarga Bangsa, Jakarta: PT. Bina Rena Pariwara, 2005.

Mufidah, Psikologi Keluarga Dalam Berwawasan Gender, Malang: UIN Malang Press, 2008.

Musa Kamil, Suami,

Madjid Nurcholish, Tradisi Islam Peran dan Fungsinya dalam pembangunan di indonesia, Jakarta: Paramadina,

Nata Abuddin, Tokoh-tokoh Pembaharuan Pendidikan Islam di Indonesia, Jakarta: PT. Rajagrafindo Persada, 2005.

Nizar Samsul, Pengantar Dasar-dasar Pemikiran Pemikiran Pendidikan Islam, Jakarta: Gaya Media Pratama, 2001.

Proyek Pembinaan Perguruan Tinggi Agama/IAIN di Jakarta Direktorat. Pembinaan Perguruan Tinggi Agama Islam, Metodologi Pengajaran Agama Islam, Jakarta: IAIN Jakarta, 1983.

Ramulyo, Moh. Idris, Asas-asas Hukum Islam Sejarah Timbul dan Berkembangnya Kedudukkan Hukum Islam dalam Sistem Hukum Indonesia, Jakarta: Sinar Grafika,1997.

Rasjidi H.M, Empat Kuliah Agama Islam Pada Perguruan Tinggi, Jakarta: Bulan Bintang, 1990.

Santoso Soegeng, Problemtika Pendidikan dan Cara Pemecahannya, Jakarta: Kreasi Pena Gading, 2001. 
Shihab, Muhammad Quraish, Membumikan Al-Qur'an Fungsi dan Peran Wahyu Dalam Kehidupan Masyarakat, Bandung: Mizan, 1994.

Shochib Moh, Pola Asuh Orang Tua, Jakarta: PT. Rineka Cipta, 2000.

Sudan, Al-Qur'an dan Panduan Kesehatan masyarakat, Yogyakarta: PT. Drama Bakti Prima Yasa, 1997.

Sugiono, Metode Penelitian Pendidikan Pendekatan Kuantitatif, Kualitatif, dan R dan D, Bandung: PT.Al fabeta, 2008.

Surahkmad Wiranto, Pengantar Penelitian Ilmiah Dasar, Metode dan tehnik, Bandung: Tarsito, 1998.

Surijdo Marwan, Cak Nur: Di Antara Sarung dan Dasi dan Musdah Mulia Tetap Berjilbab Jakarta: Yayasan Ngali Aksara, 2005.

Tim Penyusun Kamus Pusat Pembinaan dan Pengembangan Bahasa, Kamus Besar Bahasa Indonesia, Jakarta: Balai Pustaka, 1988.

Tumanggor Rusmin, Ilmu Jiwa Agama, Jakarta, Kencana, 2013.

Usman Suparman, Hukum Islam: Asas-asas dan Pengantar Studi Hukum Islam dalam Tata Hukum Indonesia, Jakarta: Gaya Media Pratama, 2002.

Yasin Fatah, Dimensi-Dimensi Pendidikan Islam, Malang: UIN Malang Press, 2008.

Yusuf Mahmud, Kamus Arab-Indonesia, Jakarta: PT. Hidakarya agung, 1989.

Yusuf Munawir, Pendidikan Bagi Anak Dengan Problema Belajar, Solo: Tiga Serangkai, 2003.

Zarkasi, Abdullah Syukri, Gontor dan Pembaharuan Pendidikan Pesantren, Jakarta: PT. Rajagrafindo Persada, 2005. 